\title{
Recognising Mineral Deposits from Cover; A Case Study Using Zircon Chemistry in the Gawler Craton, South Australia
}

\author{
Adrienne Brotodewo ${ }^{1,2, *}$, Caroline Tiddy ${ }^{1,2}{ }^{\mathbb{D}}$, Diana Zivak ${ }^{3}{ }^{-}$, Adrian Fabris ${ }^{4}$, David Giles ${ }^{1,2}$, Shaun Light ${ }^{5}$ \\ and Ben Forster 5 \\ 1 Mawson Lakes Campus, Future Industries Institute, UniSA STEM, University of South Australia, \\ Mawson Lakes, SA 5000, Australia; caroline.tiddy@unisa.edu.au (C.T.); david.giles@unisa.edu.au (D.G.) \\ 2 Mineral Exploration Cooperative Research Centre, Bentley, WA 6102, Australia \\ 3 Department of Earth and Environmental Sciences, University of Adelaide, Adelaide, SA 5005, Australia; \\ diana.zivak@adelaide.edu.au \\ 4 Geological Survey of South Australia, 12/11 Waymouth St, Adelaide, SA 5005, Australia; \\ Adrian.Fabris@sa.gov.au \\ 5 OZ Minerals, Adelaide Airport, Adelaide, SA 5950, Australia; Shaun.Light@ozminerals.com (S.L.); \\ Ben.Forster@ozminerals.com (B.F.) \\ * Correspondence: adrienne.brotodewo@unisa.edu.au
}

check for updates

Citation: Brotodewo, A.; Tiddy, C.; Zivak, D.; Fabris, A.; Giles, D.; Light, S.; Forster, B. Recognising Mineral Deposits from Cover; A Case Study Using Zircon Chemistry in the Gawler Craton, South Australia. Minerals 2021, 11, 916. https://doi. org $/ 10.3390 / \min 11090916$

Academic Editor: António Manuel Nunes Mateus

Received: 28 July 2021

Accepted: 21 August 2021

Published: 25 August 2021

Publisher's Note: MDPI stays neutral with regard to jurisdictional claims in published maps and institutional affiliations.

Copyright: (C) 2021 by the authors Licensee MDPI, Basel, Switzerland. This article is an open access article distributed under the terms and conditions of the Creative Commons Attribution (CC BY) license (https:/ / creativecommons.org/licenses/by/ $4.0 /)$.

\begin{abstract}
Detrital zircon grains preserved within clasts and the matrix of a basal diamictite sequence directly overlying the Carrapateena IOCG deposit in the Gawler Craton, South Australia are shown here to preserve $\mathrm{U}-\mathrm{Pb}$ ages and geochemical signatures that can be related to underlying mineralisation. The zircon geochemical signature is characterised by elevated heavy rare-earth element fractionation values $\left(\mathrm{Gd}_{\mathrm{N}} / \mathrm{Yb}_{\mathrm{N}} \geq 0.15\right)$ and high $\mathrm{Eu}$ ratios $\left(\mathrm{Eu} / \mathrm{Eu}^{*} \geq 0.6\right)$. This geochemical signature has previously been recognised within zircon derived from within the Carrapateena orebody and can be used to distinguish zircon associated with IOCG mineralisation from background zircon preserved within stratigraphically equivalent regionally unaltered and altered samples. The results demonstrate that zircon chemistry is preserved through processes of weathering, erosion, transport, and incorporation into cover sequence materials and, therefore, may be dispersed within the cover sequence, effectively increasing the geochemical footprint of the IOCG mineralisation. The zircon geochemical criteria have potential to be applied to whole-rock geochemical data for the cover sequence diamictite in the Carrapateena area; however, this requires understanding of the presence of minerals that may influence the HREE fractionation $\left(\mathrm{Gd}_{\mathrm{N}} / \mathrm{Yb}_{\mathrm{N}}\right)$ and /or $\mathrm{Eu} / \mathrm{Eu}^{*}$ results (e.g., xenotime, feldspar).
\end{abstract}

Keywords: zircon; geochemistry; Gawler Craton; accessory mineral; mineral exploration; cover sequences; mineral dispersion

\section{Introduction}

Mineral exploration is becoming increasingly challenging as the exploration for ore deposits moves into terranes that are buried and overlain by extensive cover sequences [1,2]. Cover sequences are commonly considered a hindrance in exploration; however, in the last $\sim 20$ years, research has increasingly focused on how the geochemical signatures of mineral systems can be translated into overlying cover sequences and therefore aid exploration [3-7]. Geochemical signatures can be transported into the overlying cover through chemical $[3,8]$ and mechanical $[5-7,9]$ processes, and are commonly preserved in resistate phases (e.g., zircon, monazite, rutile [6,10-12]). Investigation into element migration processes has been coupled with palaeotopography and landscape evolution studies to fully understand the temporal and spatial evolution of these geochemical signatures [5-7,9].

The Gawler Craton, South Australia, hosts extensive iron oxide-copper-gold (IOCG) mineralisation, including the giant Olympic Dam deposit and the large Carrapateena and 
Prominent Hill deposits (Figure 1a). The IOCG mineralisation is hosted within highly prospective Proterozoic rocks of the Olympic $\mathrm{Cu}-\mathrm{Au}$ Province in the northern and eastern Gawler Craton $[13,14]$ (Figure 1a). The Olympic $\mathrm{Cu}-\mathrm{Au}$ Province is extensively overlain by cover sequences up to several hundred meters in depth [13], effectively limiting exploration to relatively few holes drilled into geophysical targets. This leads to considerable uncertainty when geophysical features being targeted are drilled, as not all drill holes intersect mineralisation. As such, additional methods are required to assess mineral potential and recognise proximity to mineralisation. Zircon from mineralised zones of the Carrapateena IOCG deposit records geochemical characteristics that can be distinguished from distal unaltered and altered equivalents [15]. Furthermore, the use of zircon chemistry as a fertility indicator was also demonstrated for porphyry $\mathrm{Cu}$ deposits $[10,16]$. Since zircon is a common accessory phase that readily survives surficial processes and incorporation into cover, analysis of the chemical characteristics of zircon preserved within cover units may potentially provide an exploration tool. However, the potential of using zircon preserved in cover materials for IOCG exploration has not been established.

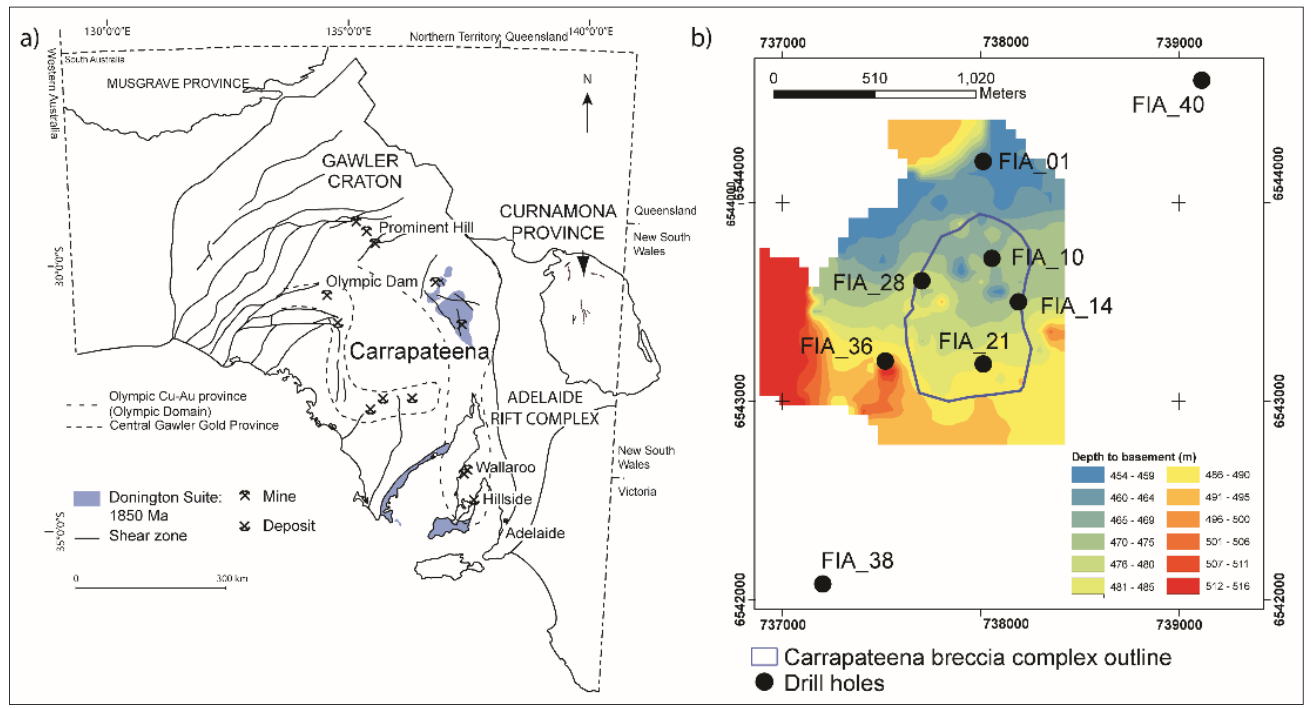

Figure 1. (a) Map of the Gawler Craton displaying key mineral deposits and the distribution of Donington Suite plutons within the basement. Modified after [17]. (b) Outline of the Carrapateena orebody over a depth to basement map (modified after [11]). The location of drill holes from which samples of the basal diamictite in the overlying cover sequence were taken are shown. The location of the Carrapateena deposit is highlighted in (a).

In this paper, the zircon $\mathrm{U}-\mathrm{Pb}$ and trace element composition of in situ zircon grains from a barren basal diamictite overlying the Carrapateena IOCG deposit is assessed to determine if there is any similarity with that of zircon grains from the underlying mineralised basement rocks. The results are used to determine if zircon chemistry can be used to extend the geochemical signature of an IOCG deposit in cover sequences, and therefore be a useful tool for IOCG exploration in areas of thick cover. The limitations and implications of such an exploration tool are then discussed.

\section{Background}

The Gawler Craton, South Australia is one of the largest global iron oxide-coppergold (IOCG) provinces and hosts several large deposits including Olympic Dam, Prominent Hill, and Carrapateena [13,18] (Figure 1a). This metallogenic province hosts numerous prospects and is subject to continued exploration. Copper-gold mineralisation is widely regarded as predominantly forming during a major tectonothermal and magmatic event at 1600-1570 Ma $[13,14]$. IOCG mineralisation is hosted within various rock units, including the ca. 1850 Ma Donington Suite (Carrapateena: [12,19-21]); 1750 Ma Wallaroo Group 
(Emmie Bluff: [22]); ca. 1595-1575 Ma Hiltaba Suite granites (Olympic Dam: [23,24]) and the ca. 1595-1587 Ma Gawler Range Volcanics (Prominent Hill: [25]). Mineralisation is overlain by extensive Neoproterozoic to Cambrian cover sequences of the Adelaide Rift Complex and Stuart Shelf [26].

The Carrapateena IOCG deposit was discovered in 2005 in the eastern Gawler Craton (Figure 1b). Mineralisation occurs within a vertical pipe-like breccia complex, termed the "Carrapateena Breccia Complex" [12,27]. The Carrapateena Breccia Complex is a clast- to matrix-supported breccia developed within a variably foliated and/or sheared ca. $1850 \mathrm{Ma}$ Donington Suite batholith $[12,20,28]$. The clasts comprise medium-grained meta-granite to diorite and quartz veins that are variably altered to chlorite, sericite, and hematite. The matrix is dominated by hematite and quartz and is sericite-altered [12]. The Carrapateena Breccia Complex is intruded by several predominantly mafic dykes [29].

The Carrapateena deposit is unconformably overlain by up to $\sim 470 \mathrm{~m}$ thick Neoproterozoic sedimentary cover consisting of the Umberatana and Wilpena groups of the Stuart Shelf $[12,26,27]$. These Cryogenian to Ediacaran sedimentary packages indicate the unconformity at the basement-cover interface, which represents an approximate 1000million-year gap in the geological record as a result of extensive erosion of intervening units or a halt in deposition of sediments across the region [30-32]. The Umberatana sequences comprise gritty siltstones to sandstones with minor dolomitic interbeds and a basal conglomerate at the basement-cover interface [33]. The basal conglomerate typically comprises well-rounded granite, volcanic, quartz, and hematite clasts in a fine sandy matrix [12,27]. These clasts are inferred to be derived from the underlying basement rocks [34]. Interpreted depositional environments for the Umberatana Group include glacial, interglacial, and marine environments [35]; however, the depositional history of the cover sediments that specifically overlie the Carrapateena deposit is uncertain.

\section{Exploration through Cover}

Exploration in covered regions is commonly reliant on geophysical and geochemical interpretations [36,37]. In areas of thin cover, geochemical sampling is commonly successfully used in mineral exploration and uses elevated pathfinder elements associated with underlying mineralisation, and, in some instances, can extend the geochemical halo of the mineralising system [4,9,38-42].

Geochemical anomalies associated with mineralisation can migrate into overlying cover sequence materials through chemical processes, usually driven by water, gas, or physical processes [38]. Fluid conditions, such as $\mathrm{pH}$, Eh, and temperature, have a large influence on the mobility of elements, and largely control whether a host rock is enriched or depleted during chemical weathering and mobilisation [38,43-45].

Alternatively, geochemical haloes in cover materials above a mineralising system can be generated by mechanical processes, which usually involve erosion of underlying bedrock, transportation, and lateral physical dispersion of the orebody itself $[5,6,38,43,46,47]$. Geochemical anomalies associated with the transport of the orebody are generated in the direction of transportation, and can occur in several environments including aeolian, fluvial, coastal, hillslope, and glacial environments [6,7,42,47].

\section{Materials and Methods}

\subsection{Sample Selection and Preparation}

A total of 8 samples of the basal material at the basement-cover unconformity were used in this study (Table 1). Four of these samples directly overlie the Carrapateena IOCG deposit (Figure 1b). Sample collection and access to drill core was made available by OZ Minerals. Drill holes were selected to provide a transect across the Carrapateena deposit. Samples collected were of half core and approximately $20-40 \mathrm{~cm}$ in length. The intervals selected were within a metre of the basement-cover interface and were chosen for their high clast content as well as the presence of hematite-dominated clasts. 
Table 1. Description of basal diamictite samples used for whole-rock geochemical analysis and zircon analysis. Location of samples are shown in Figure 1b.

\begin{tabular}{|c|c|c|c|c|c|}
\hline Sample & Drill Hole & $\begin{array}{l}\text { Number } \\
\text { of } \\
\text { Zircons }\end{array}$ & Sample Description & $\begin{array}{l}\text { Zircon Location } \\
\text { (Number of } \\
\text { Analyses) }\end{array}$ & $\begin{array}{c}\text { Interesting Zircon } \\
\text { Geochemical } \\
\text { Characteristics }\end{array}$ \\
\hline FIA_01 & $\begin{array}{c}\text { CAR010 }(\sim 1 \mathrm{~km} \\
\text { north of the } \\
\text { orebody })\end{array}$ & 6 & $\begin{array}{c}\text { Matrix-supported, poorly sorted, } \\
\text { polymictic diamictite. Matrix: } \\
\text { fine-medium-grained, brown/reddish } \\
\text { sandstone. Clasts: cobble sized, } \\
\text { subangular to subrounded Fe-altered } \\
\text { granite }(\sim 80-90 \% \text {, up to } 7 \mathrm{~cm}) ; \\
\text { well-rounded volcanic }(\sim 5 \%) \text {, sedimentary } \\
\text { rock }(\sim 5 \%) .\end{array}$ & $\begin{array}{l}\text { Matrix: (5); Clasts: } \\
\text { Fe-altered granite (1) }\end{array}$ & $\begin{array}{l}\text { Matrix: Heavy rare-earth } \\
\text { element fractionation }(\mathrm{HREE} \\
\text { Frac) } \geq 0.15 \\
\mathrm{Eu} / \mathrm{Eu}^{*} \leq 0.6 \\
\text { Clast: HREE Frac } \leq 0.15 \\
\mathrm{Eu} / \mathrm{Eu}^{*} \leq 0.6\end{array}$ \\
\hline FIA_10 & CAR019 & 6 & $\begin{array}{c}\text { Matrix-supported diamictite. Matrix: } \\
\text { medium-grained brown sandstone } \\
\text { preserves chaotic bedding to planar } \\
\text { laminated bedding. Clasts: angular to } \\
\text { subrounded hematite, granite, quartz, } \\
\text { mafic, and volcanic clasts. }\end{array}$ & $\begin{array}{l}\text { Matrix: (5); Clasts: } \\
\text { hematite (1) }\end{array}$ & $\begin{array}{l}\text { Matrix: HREE Frac } \geq 0.15 \\
\qquad \mathrm{Eu} / \mathrm{Eu}^{*} \geq 0.6 \\
\text { Clast: } \mathrm{HREE} \text { Frac } \leq 0.15 \\
\mathrm{Eu} / \mathrm{Eu}^{*} \leq 0.6\end{array}$ \\
\hline FIA_14 & CAR058 & 14 & $\begin{array}{l}\text { Poorly sorted, polymictic, clast-supported } \\
\text { diamictite with rounded to subrounded } \\
\text { quartz }(\sim 80 \%), \mathrm{K} \text {-feldspar }(\sim 5-10 \%) \text {, } \\
\text { rounded, sericite-altered, volcanic clasts } \\
(\sim 5 \%), \text { well-rounded to angular granite } \\
(\sim 5 \%) \text {, and angular hematite }(\sim 5 \%) \text {. }\end{array}$ & $\begin{array}{c}\text { Matrix: (5); Clasts: } \\
\text { sandstone (5), granite } \\
\text { (3), quartz (1) }\end{array}$ & $\begin{array}{l}\text { Matrix: HREE Frac } \geq 0.15 \\
\qquad \mathrm{Eu} / \mathrm{Eu}^{*} \geq 0.6 \\
\text { Clast: } \mathrm{HREE} \text { Frac } \geq 0.15 \\
\mathrm{Eu} / \mathrm{Eu}^{*} \geq 0.6\end{array}$ \\
\hline FIA_21 & CAR024 & 11 & $\begin{array}{l}\text { Polymictic, clast-supported diamictite. } \\
\text { Matrix: medium-grained, brown } \\
\text { sandstone. Clasts: subrounded to } \\
\text { subangular granite }(\sim 80 \%) \text {, mafics }(<5 \%) \text {, } \\
\text { volcanics }(\sim 15 \%) \text {, and quartz }(<5 \%) \text {. }\end{array}$ & $\begin{array}{c}\text { Matrix: (2); Clasts: } \\
\text { granite (5), hematite } \\
\text { breccia (4) }\end{array}$ & $\begin{array}{l}\text { Matrix: HREE Frac } \leq 0.15 \\
\qquad \mathrm{Eu} / \mathrm{Eu}^{*} \leq 0.6 \\
\text { Clast: } \mathrm{HREE} \text { Frac } \geq 0.15 \\
\mathrm{Eu} / \mathrm{Eu}^{*} \geq 0.6\end{array}$ \\
\hline FIA_28 & CAR034 & 19 & $\begin{array}{l}\text { Poorly sorted, polymictic, clast-supported } \\
\text { diamictite. Matrix: brown, } \\
\text { medium-grained sandstone. Clasts: } \\
\text { well-rounded granite (up to } 5 \mathrm{~cm} \text {, up to } \\
\sim 40 \%) \text {, subangular hematite }(\sim 10 \%) \text {, mafic } \\
\text { rock (angular, } \sim 5 \%) \text {, hematite breccia } \\
(\sim 2 \%) \text {, quartz }(\sim 15 \%) \text {, volcanic rock } \\
(\sim 20 \%) \text {, other (different) types of granite } \\
(\sim 10 \%) .\end{array}$ & $\begin{array}{l}\text { Matrix: (2); Clasts: } \\
\text { volcanics (14), } \\
\text { sandstone (1), quartz } \\
\quad(1), \text { siltstone (1) }\end{array}$ & $\begin{array}{l}\text { Matrix: HREE Frac } \leq 0.15 \\
\qquad \mathrm{Eu} / \mathrm{Eu}^{*} \leq 0.6 \\
\text { Clast: } \mathrm{HREE} \text { Frac } \geq 0.15 \\
\quad \mathrm{Eu} / \mathrm{Eu}^{*} \geq 0.6\end{array}$ \\
\hline FIA_36 & $\begin{array}{l}\text { CAR042 }(\sim 0.2 \mathrm{~km} \\
\text { west of the main } \\
\text { orebody) }\end{array}$ & 13 & $\begin{array}{l}\text { Well to moderately sorted, } \\
\text { clast-supported, polymictic diamictite. } \\
\text { Matrix: brown, medium-grained } \\
\text { sandstone. Clasts: subangular to rounded } \\
\text { Fe-, ser-altered (greenish tinge) granite } \\
(\sim 40 \%) \text {, hematite breccia }(\sim 10 \%) \text {, quartz } \\
(\sim 10 \%) \text {, volcanics }(\sim 40 \%), \text { mafics }(<5 \%) \text {. }\end{array}$ & $\begin{array}{l}\text { Matrix: (1); Clasts: } \\
\text { volcanics (1), } \\
\text { K-feldspar (1), } \\
\text { unknown host }(10)\end{array}$ & $\begin{array}{c}\text { Unknown: HREE Frac } \geq 0.15 \\
\mathrm{Eu} / \mathrm{Eu}^{*}=\text { Variable }\end{array}$ \\
\hline FIA_38 & $\begin{array}{l}\text { DD13CAR117W1 } \\
\qquad(\sim 1 \mathrm{~km} \\
\text { south-west of the } \\
\text { main orebody) }\end{array}$ & 7 & $\begin{array}{l}\text { Poorly sorted, clast-supported diamictite. } \\
\text { Matrix: medium-grained sandstone. } \\
\text { Clasts: well-rounded, pebble to boulder } \\
\text { sized granite }(\sim 60-70 \%) \text {, angular hematite } \\
\text { breccia clasts }(\sim 15 \%) \text {, itself containing } \\
\text { visible altered granite and siltstone clasts, } \\
\text { sericite-altered mafics with phenocrystic } \\
\text { feldspar }(\sim 5 \%) \text {, well-rounded } \\
\text { hematite-rich rock }(\sim 5 \%) .\end{array}$ & Unknown host (7) & $\begin{array}{c}\text { Unknown: HREE Frac } \leq 0.15 \\
\mathrm{Eu} / \mathrm{Eu}^{*}<0.6\end{array}$ \\
\hline FIA_40 & $\begin{array}{l}\text { CAR011 }(\sim 1 \mathrm{~km} \\
\text { north-east of the } \\
\text { main orebody) }\end{array}$ & 40 & $\begin{array}{l}\text { Poorly sorted, polymictic, clast-supported } \\
\text { diamictite. Matrix: medium-grained } \\
\text { sandstone. Clasts: medium to large } \\
\text { pebbles of angular to subrounded } \\
\text { hematite-rich clasts and altered granite. }\end{array}$ & $\begin{array}{l}\text { Matrix: (5); Clasts: } \\
\text { Fe-altered granite (1) }\end{array}$ & $\begin{array}{c}\text { Unknown: HREE Frac } \geq 0.15 \\
\mathrm{Eu} / \mathrm{Eu}^{*}>0.6\end{array}$ \\
\hline
\end{tabular}

Where possible, existing thin sections of sampled intervals owned by OZ Minerals were used for zircon analyses. Remaining samples were cut and prepared into thin section blocks at the University of South Australia. Thin sections were made by Adelaide Petrographics Pty Ltd. (Stepney, South Australia, Australia).

Three samples (FIA_36, FIA_38, and FIA_40) were crushed and sieved at the University of South Australia to obtain a 79-400 $\mu \mathrm{m}$ fraction and to create zircon mounts. Samples 
were panned, and magnetic minerals separated with a hand magnet. Zircon grains were hand-picked and mounted in epoxy resin discs. Care was taken not to be biased when selecting the grains, ensuring all sizes, colours, and shapes were selected.

\subsection{Whole-Rock Geochemical Analysis}

Seven samples were submitted for analysis at Bureau Veritas, Wingfield, South Australia for whole-rock geochemistry (Supplementary Material S1). For each sample, 100-150 g separates were prepared prior to zircon separation to ensure the sample was representative of the whole interval used. Samples were crushed and prepared using standard methods (https:/ / www.bureauveritas.com.au/ (accessed on 20 August 2021)). Details of analytical methods for each element are given in Supplementary Material S1. Additional geochemical data from the OZ Minerals database was also used where possible.

\subsection{Zircon $\mathrm{U}-\mathrm{Pb}$ Geochronology and Geochemistry}

Zircon morphology, textural, $\mathrm{U}-\mathrm{Pb}$, and geochemical analyses were carried out at the University of Adelaide, Australia. Polished thin sections for FIA_01, FIA_10, FIA_14, FIA_21, FIA_28, and FIA_36 were analysed for zircon morphology and to retain the textural context of the zircon grains and their hosts (clasts or the matrix) where possible. Zircon grain mounts of samples FIA_36, FIA_38, and FIA_40 were also analysed for zircon morphology. The internal structures of zircon grains were imaged under cathodoluminescence (CL) on the MLA Quanta SEM 600 to identify the crystallisation history of individual grains through internal texture characterisation (Supplementary Material S2).

$\mathrm{U}-\mathrm{Pb}$ data was collected from both thin section and grain mount samples in conjunction with rare-earth element and trace-element geochemistry using laser ablation inductively coupled mass spectrometry (LA-ICP-MS) on a Resonetics M-50-LR 193-nm Excimer laser microprobe coupled to an Agilent 7700cx Quadrupole ICP-MS. Five shots were fired prior to each analysis to remove surface contamination. Zircons were ablated at a frequency of $5 \mathrm{~Hz}$, intensity of $2.1 \mathrm{~J} / \mathrm{cm}^{2}$, and a spot size of 29 and $13 \mu \mathrm{m}$ (Supplementary Material S2 and S3). The smaller spot size was used for zircon grains $<20 \mu \mathrm{m}$, or for analysing specific textural domains within individual zircon grains. The acquisition time of each analysis was $60 \mathrm{~s}$, comprising $30 \mathrm{~s}$ of background measurement and $30 \mathrm{~s}$ of ablation. The smaller spot sizes were analysed using $30 \mathrm{~s}$ background measurement, followed by $15 \mathrm{~s}$ ablation, and $15 \mathrm{~s}$ background to minimise isotopic fractionation-associated high depthto-width ratio of the resulting ablation craters [48]. Samples were analysed in multiple analytical sessions as outlined in Supplementary Material S3. Zircon data were corrected for mass bias, elemental fractionation, and instrument drift based on the measured isotopic ratios of the primary zircon references GJ-1 and Plešovice, in standard bracketing procedures every 20 unknown analyses. Plešovice yielded respective weighted mean ages of ${ }^{206} \mathrm{~Pb} /{ }^{238} \mathrm{U}=340.14 \pm 0.84 \mathrm{Ma}(\mathrm{MSWD}=1.15, \mathrm{n}=36)$, which is within uncertainty of the known values for the standards. See Supplementary Material S3 for more detail. Data processing was conducted using Iolite software 4 [49], with $\mathrm{Zr}$ as an internal standard and NIST 610 glass standard used to calculate elemental concentrations. Zr was used over $\mathrm{Si}$ as the internal standard due to less fractionation/bias [50]. It was assumed that samples contained $49.7 \mathrm{wt} \% \mathrm{Zr}$. The resulting compositions are within $15 \%$ accuracy of the published trace element data for GJ-1 zircon standard, except for La, which is above $15 \%$ accuracy due to its low concentration in zircon. Analytical uncertainties are given at $2 \sigma$, with weighted mean and intercept calculations given at the $95 \%$ confidence level. Samples with high common $\mathrm{Pb}$ and $\mathrm{U}$ were removed from concordia plots. Contamination by small mineral inclusions is common in zircon; therefore, the dataset was filtered to exclude contaminated analyses for zircon geochemical analyses. Analyses were excluded if there were obvious disruptions/spikes in counts per second (CPS) signals as a result of large inclusions, along with those with $\mathrm{Al}>5000$ ppm, Fe $>5000$ ppm for Fe oxides, La > 5 ppm for apatite contamination, and $\mathrm{Ti}>50$ ppm for $\mathrm{Ti}-(\mathrm{Fe})$ oxides. The zircon considered to 
be inclusion-free (using this criteria) overlap with analyses that were not excluded from concordia plots due to high common Pb and CPS disruptions (Supplementary Material S3).

\section{Results}

\subsection{Sample Descriptions}

Descriptions for the eight samples from the basal material overlying the Carrapateena deposit area used in this study are given in Table 1. Samples vary from clast- to matrixsupported and are mostly poorly sorted, with clasts ranging in size from $<5 \mathrm{~mm}$ up to cobbles. The clasts range from angular to rounded in shape. The samples are polymictic, with clasts comprising granite, granite breccia, hematite breccia, sandstone, volcanics, quartz, and sedimentary rocks that have undergone variable degrees of Fe-, sericite-, and potassic alteration (Table 1; Figure 2). The poorly sorted, polymictic, and angular to rounded nature of the clasts in the basal material indicates that the material overlying the Carrapateena deposit area has a diamictite texture rather than conglomerate, as described by previous authors $[12,27,33,51]$. The basal cover material is herein described as a diamictite.
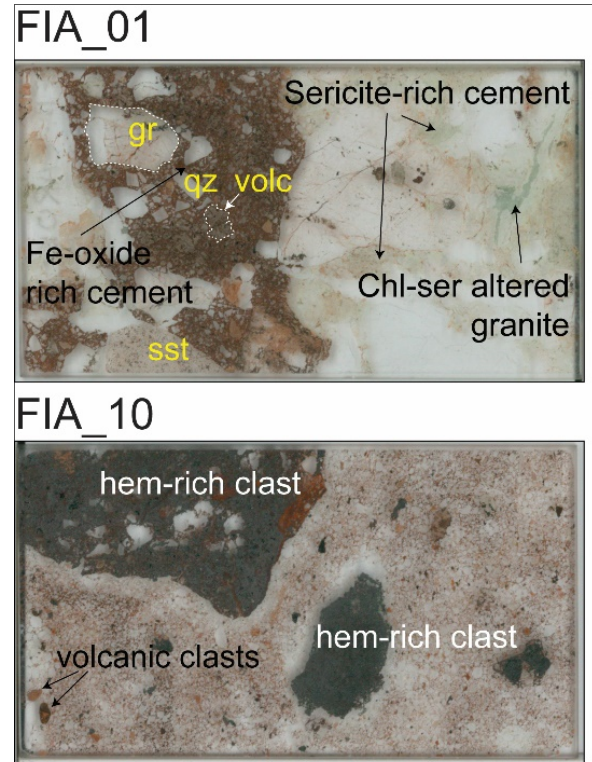

FIA 14

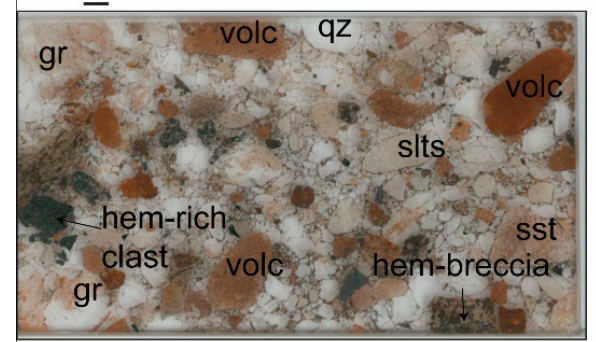

FIA_21

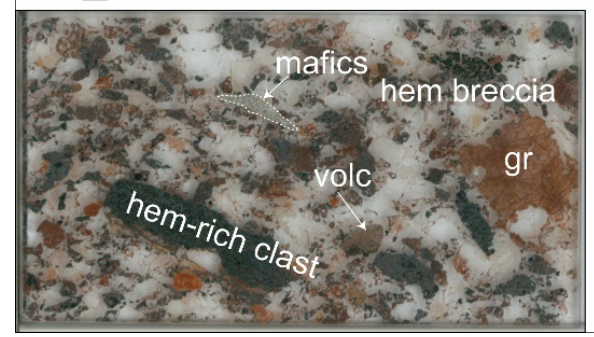

FIA_28

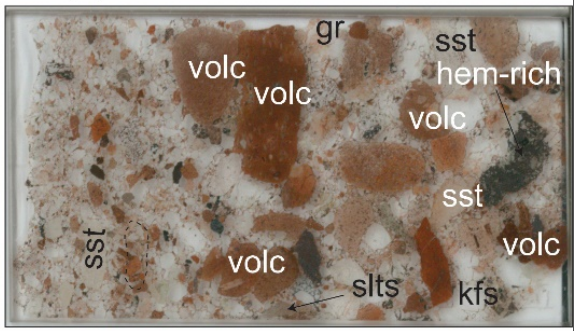

FIA 36

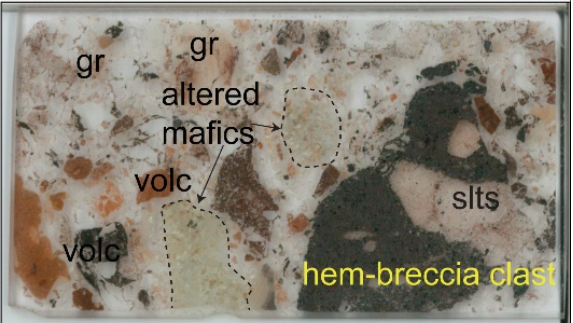

\section{FIA_38}
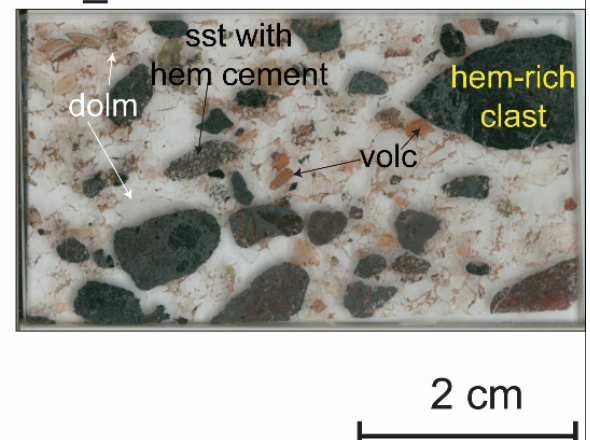

Figure 2. Thin section photos of the basal diamictite samples used in this study. Drill hole locations are shown in Figure 1b. Mineral abbreviations: gr, granite; qz, quartz; volc, volcanic; sst, sandstone; kfs, k-feldspar; slts, siltstone; chlr-ser, chlorite-sericite; hem, hematite. 


\subsection{Whole-Rock Geochemistry}

Samples display a range of $\mathrm{SiO}_{2}$ values $(\sim 50-80 \mathrm{wt} \%)$, with decreasing $\mathrm{Fe}_{2} \mathrm{O}_{3}$ content with increasing $\mathrm{SiO}_{2}$ (Figure 3a). Copper content is variable, with the highest values in FIA_21 ( 90 ppm), and shows a slight negative correlation with $\mathrm{SiO}_{2}$ (Figure 3b). Chondritenormalised rare-earth element (REE) diagrams show that all samples display enrichment in light rare-earth elements (LREEs), mostly with negative Eu anomalies (Figure 3c).

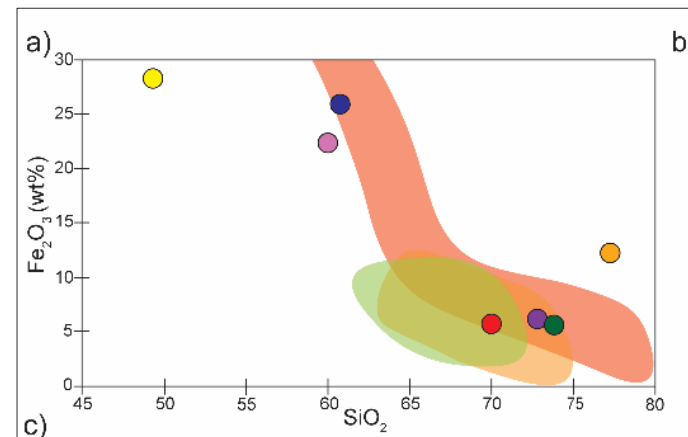

b)
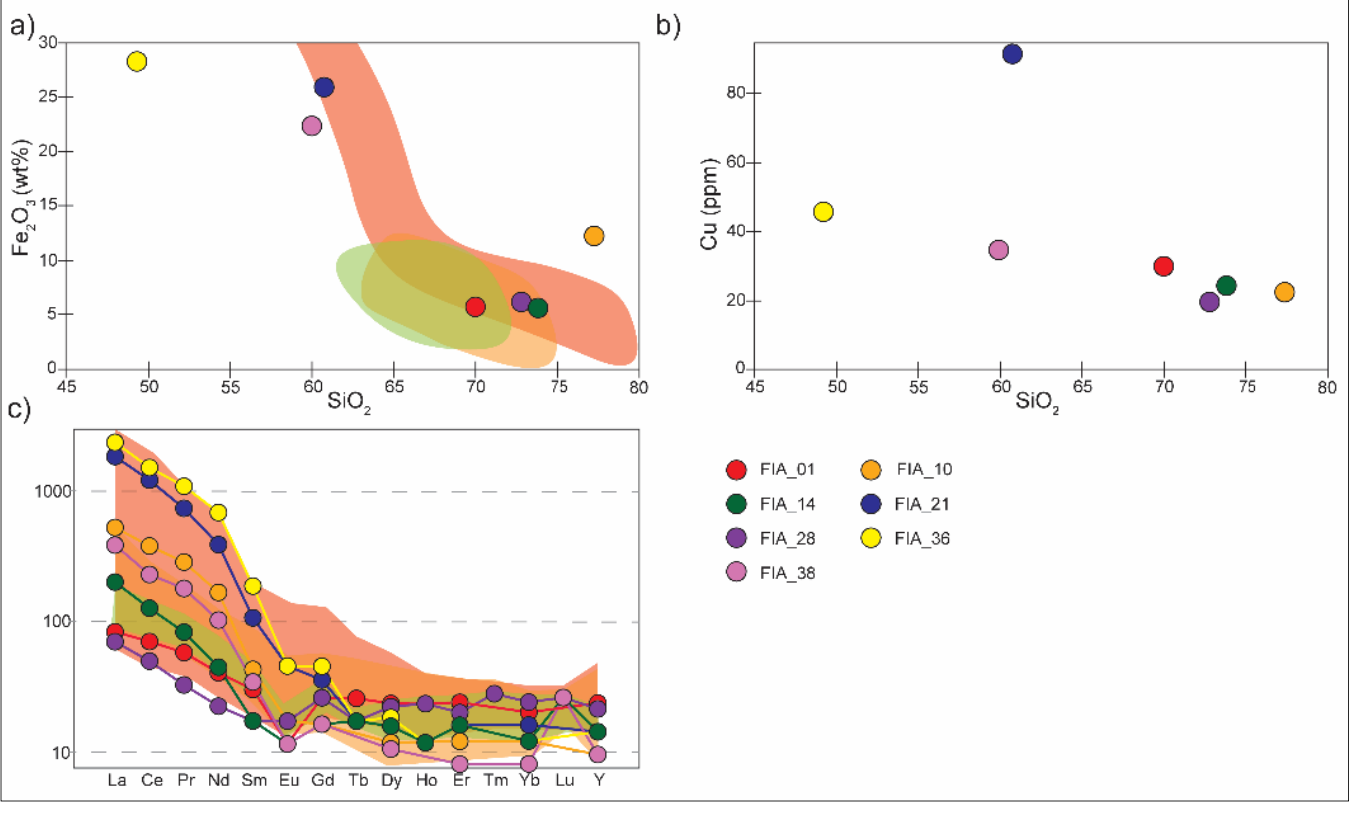

Figure 3. Whole-rock geochemical data for basal diamictite samples used in this study. (a) Bivariate plot of $\mathrm{SiO}_{2} \mathrm{vs} \mathrm{Fe}_{2} \mathrm{O}_{3}$; (b) bivariate plot of $\mathrm{SiO}_{2}$ vs. $\mathrm{Cu}$; (c) Chondrite normalised REE diagrams displaying REE patterns for samples used in this study. Data normalised to values of [52]; sample locations are shown in Figure 1b. Fields show whole-rock geochemistry of regional unaltered (green) and altered (orange) Donington Suite, and Donington Suite from the Carrapateena deposit (red) (data from [15]).

\subsection{Zircon Morphology}

Zircon grains from the matrix and clasts are euhedral to subhedral in shape, with aspect ratios up to 1:3 and sizes ranging from 50-200 $\mu \mathrm{m}$ (Figure 4). A large portion of zircons preserved in the matrix are largely fractured with only fragments of a grain preserved, while the zircons hosted within clasts are less fragmented (Figure 4). Variable weak to distinct oscillatory zoning and minor recrystallisation of rims is present (Figure 4; Supplementary Material S2). 


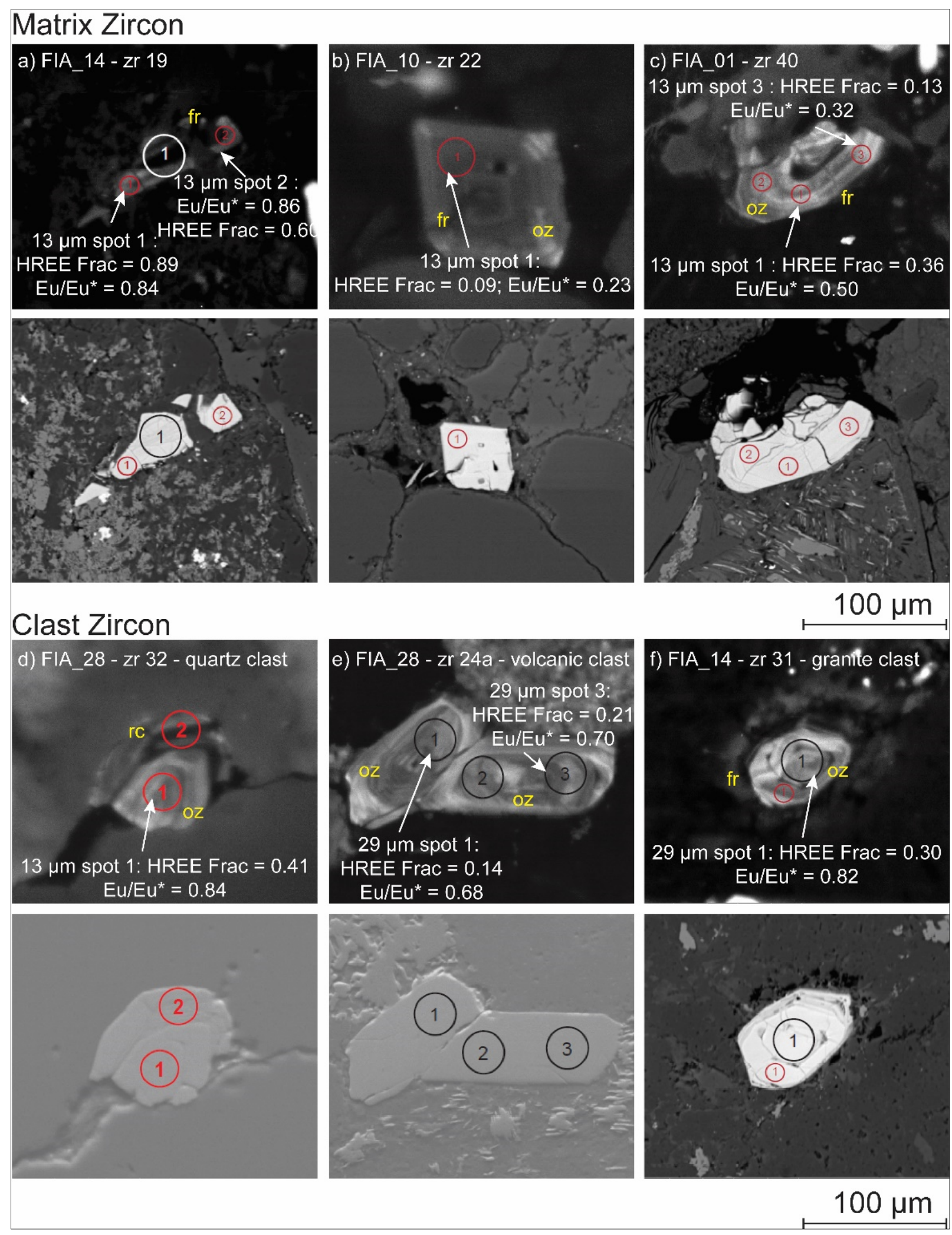

Figure 4. Representative cathodoluminescence (CL) and backscattered electron (BSE) images of zircon from basal diamictite samples used in this study. Representative zircon from the matrix (a-c) and quartz, volcanic, and granite clasts (d-f) are shown with locations of spot analyses (red circles $=13 \mu \mathrm{m}$, black circles $=29 \mu \mathrm{m}$ ) and HREE Frac content for each analysis. Geochemistry of spot locations are outlined in Figure 8c. Abbreviations used: oz: oscillatory zoning; fr: fractures; rc: recrystallisation. 


\subsection{Zircon $\mathrm{U}-\mathrm{Pb}$ Analysis}

$\mathrm{U}-\mathrm{Pb}$ data was collected for all basal diamictite samples.

Sample FIA_01: A total of 57 analyses were made on 18 zircon grains. Of these analyses, 46 were excluded due to high common lead. The 11 analyses remaining are located within the matrix, sandstone, granite, and Fe-altered granite clasts. A U-Pb concordia plot of these analyses yields an upper intercept age of $1853 \pm 120 \mathrm{Ma}$ (MSWD = 11.9; Figure 5a). Two analyses were concordant $(<5 \%)$ and used for age calculations (located within the matrix and Fe-altered granite clasts). These two grains yield an average ${ }^{207} \mathrm{~Pb} /{ }^{206} \mathrm{~Pb}$ age of $1793 \pm 100($ MSWD $=0.84, \mathrm{n}=2$ ), which is within error of the upper intercept.
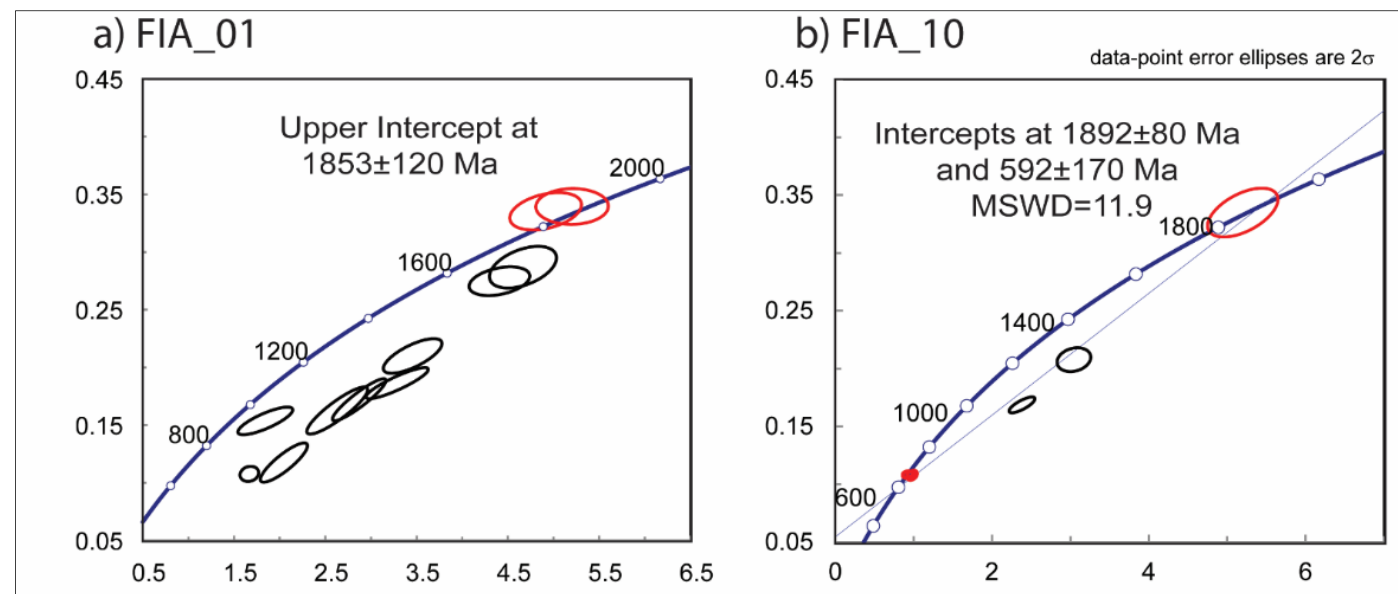

c) FIA_14

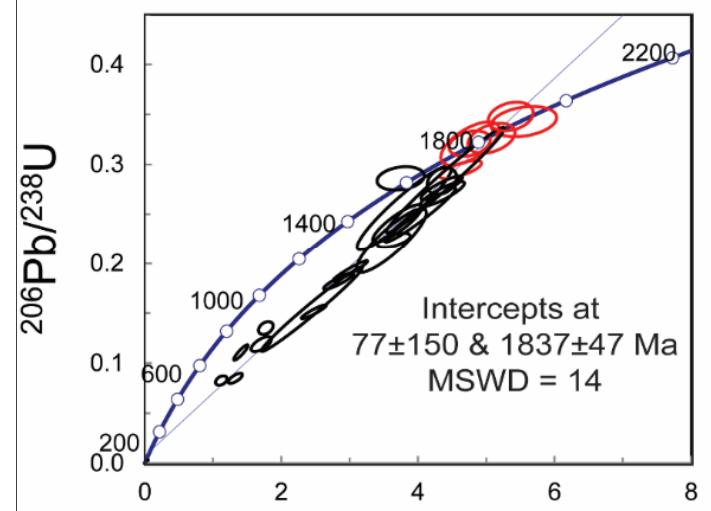

d) FIA_21

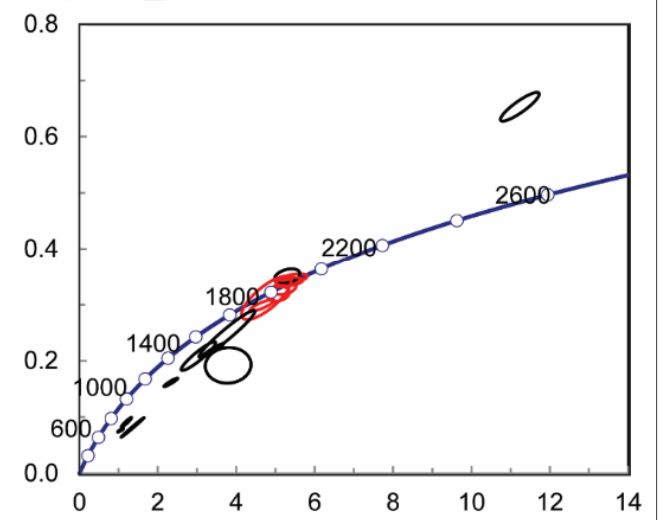

e) FIA_36

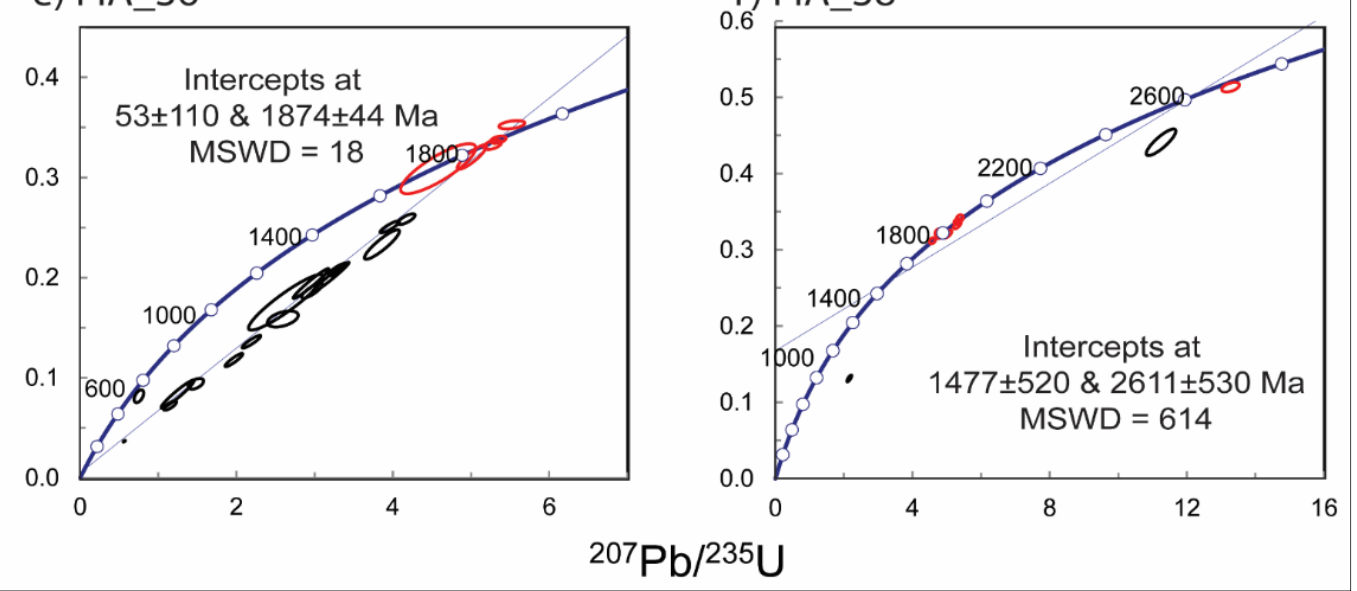

Figure 5. U-Pb Concordia plots. (a-f) U-Pb concordia plot for basal diamictite samples overlying the Carrapateena deposit. Sample locations are shown in Figure 1b. 
Sample FIA_10: A total of 13 analyses were made on 12 zircon grains. Of these analyses, seven were excluded due to high common lead and disrupted signals. The six analyses that were not excluded are located within a hematite clast and the diamictite matrix. A $\mathrm{U}-\mathrm{Pb}$ concordia plot of these analyses yields an upper intercept age of $1892 \pm 180 \mathrm{Ma}$ and a lower intercept of $592 \pm 170 \mathrm{Ma}$ (MSWD = 11.9; Figure 5b). Four analyses were concordant $(<5 \%)$ and used for age calculations where two populations of zircon are present. One grain located within a hematite clast has a ${ }^{207} \mathrm{~Pb} /{ }^{206} \mathrm{~Pb}$ age of $1779 \pm 111 \mathrm{Ma}$, within error of the upper intercept. The other three grains yield an average ${ }^{207} \mathrm{~Pb} /{ }^{206} \mathrm{~Pb}$ age of $672 \pm 49 \mathrm{Ma}$ (MSWD = 2, n =3), within error of the lower intercept.

Sample FIA_14: A total of 40 analyses were made on 23 zircon grains. Of these analyses, 14 were excluded due to high common lead and disrupted signals. The 26 remaining analyses are located within the diamictite matrix and sandstone, quartz, granite, and volcanic clasts. A U-Pb concordia plot of these analyses yields an upper intercept age of $1837 \pm 47 \mathrm{Ma}$ and a lower intercept of $77 \pm 150 \mathrm{Ma}$ (MSWD =14; Figure 5c). Six of these analyses were concordant $(<5 \%)$ and used for age calculations (located within sandstone clasts and the matrix) and yield an average ${ }^{207} \mathrm{~Pb} /{ }^{206} \mathrm{~Pb}$ age of $1819 \pm 27 \mathrm{Ma}$ (MSWD $=0.64, \mathrm{n}=6$ ), within error of the upper intercept.

Sample FIA_21: A total of 39 analyses were made on 20 zircon grains. Of these analyses, 23 were excluded due to high common lead and disrupted signals. The 16 analyses that were not excluded are located within the matrix and hematite breccia, granite, and quartz clasts. Six of these analyses were concordant $(<5 \%)$ and used for age calculations (located within matrix and hematite breccia/granite clasts) and yield an average ${ }^{207} \mathrm{~Pb} /{ }^{206} \mathrm{~Pb}$ age of $1849 \pm 13 \mathrm{Ma}(\mathrm{MSWD}=0.63, \mathrm{n}=6)$.

Sample FIA_28: A total of 42 analyses were made on 27 zircon grains. Of these analyses, 21 were excluded due to high common lead and disrupted signals. The remaining 21 analyses are located within the matrix and volcanic, siltstone, sandstone, and quartz clasts. A U-Pb concordia plot of these analyses yields an upper intercept age of $2003 \pm 270 \mathrm{Ma}$ and a lower intercept of $811 \pm 480 \mathrm{Ma}$ (MSWD = 31; Figure 6a). Thirteen of these analyses were concordant $(<5 \%)$ and used for age calculations (located within the matrix and volcanic/siltstone/sandstone clasts) and yield variable ${ }^{207} \mathrm{~Pb} /{ }^{206} \mathrm{~Pb}$ ages (Figure $6 \mathrm{~b}$ ). The zircon located within the sandstone clast yields a $2503 \pm 17 \mathrm{Ma}$ age. The zircon within the matrix has an age of $1864 \pm 24 \mathrm{Ma}$ and the zircon located within the siltstone has an age of $1722 \pm 36 \mathrm{Ma}$. Ten grains are host within volcanic clasts and yield an average ${ }^{207} \mathrm{~Pb} /{ }^{206} \mathrm{~Pb}$ age of $1590 \pm 22 \mathrm{Ma}(\mathrm{MSWD}=1.9, \mathrm{n}=10$ ).

Sample FIA_36: A total of 49 analyses were made on 37 zircon grains. Of these analyses, 28 were excluded due to high common lead and disrupted signals. The remaining 21 analyses are located within unknown hosts, the matrix and K-feldspar, granite, and volcanic clasts. A U-Pb concordia plot of these analyses yields an upper intercept age of $1874 \pm 44 \mathrm{Ma}$ and a lower intercept of $53 \pm 110 \mathrm{Ma}$ (MSWD = 18; Figure 5e). Five of these analyses were concordant $(<5 \%)$ and used for age calculations (located within a Kfeldspar clast and unknown hosts) and yield an average ${ }^{207} \mathrm{~Pb} /{ }^{206} \mathrm{~Pb}$ age of $1860 \pm 24 \mathrm{Ma}$ $(\mathrm{MSWD}=1.6, \mathrm{n}=5)$, within error of the upper intercept. 


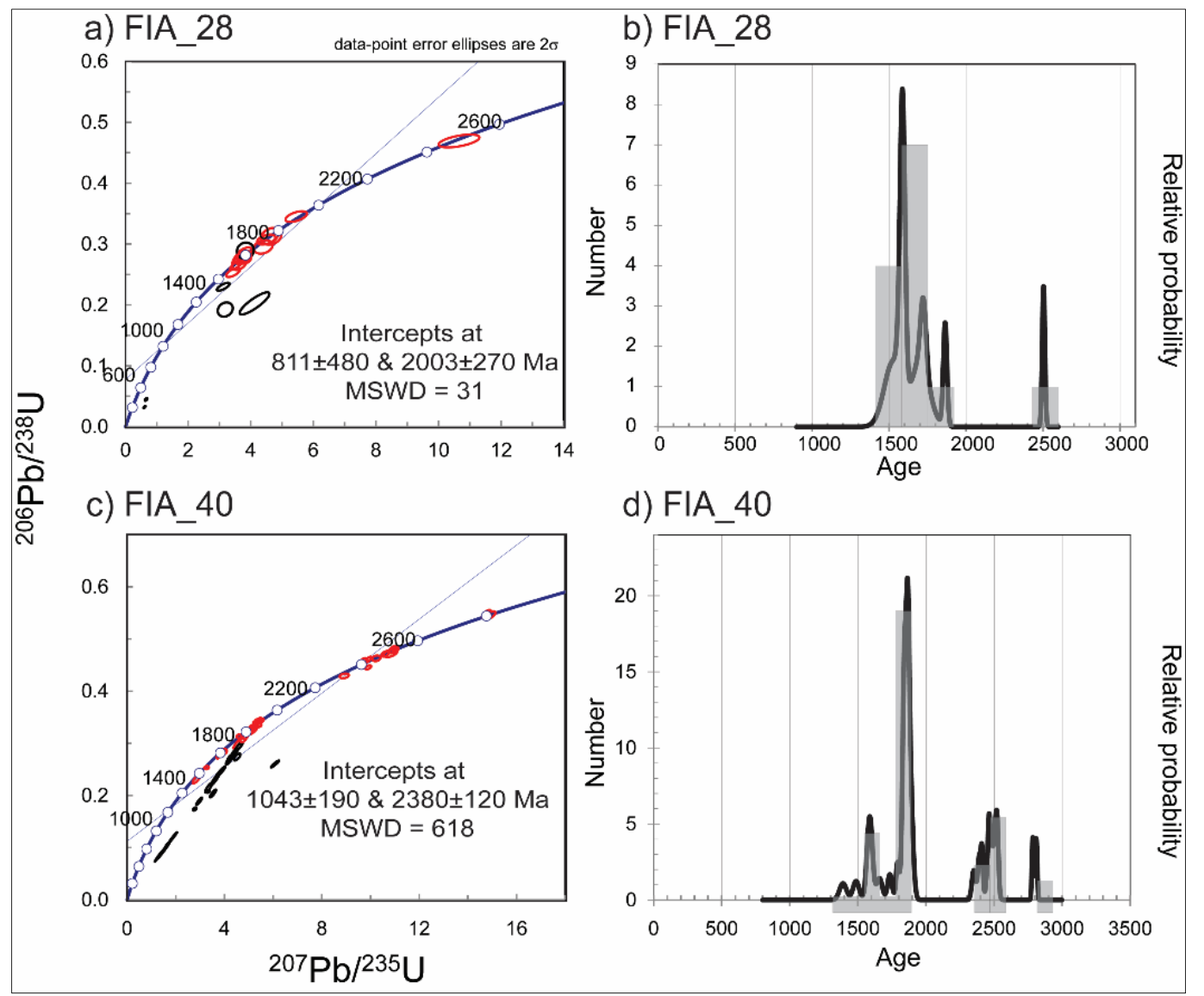

Figure 6. $\mathrm{U}-\mathrm{Pb}$ concordia plots for basal diamictite samples overlying the Carrapateena deposit. (a,b) FIA_28 U-Pb concordia plot and histogram; (c,d) FIA_40 U-Pb concordia plot and histogram. Sample locations are shown in Figure 1b.

Sample FIA_38: A total of 18 analyses were made on 18 zircon grains. Of these analyses, eight were excluded due to high common lead and disrupted signals. The 10 analyses not excluded are located within unknown hosts. A U-Pb concordia plot of these analyses yields an upper intercept age of $2611 \pm 530 \mathrm{Ma}$ and a lower intercept of $1477 \pm 520 \mathrm{Ma}$ (MSWD = 614; Figure 5f). Eight of these analyses were concordant $(<5 \%)$ and used for age calculations. One grain has a ${ }^{207} \mathrm{~Pb} /{ }^{206} \mathrm{~Pb}$ age of $2710 \pm 23 \mathrm{Ma}$, four grains yield an average age of $1863 \pm 14 \mathrm{Ma}(\mathrm{MSWD}=1.14, \mathrm{n}=4)$, and another, younger population occurs at $1744 \pm 62 \mathrm{Ma}(\mathrm{MSWD}=3.7, \mathrm{n}=3)$.

Sample FIA_40: A total of 68 analyses were made on 35 zircon grains. Of these analyses, 10 were excluded due to high common lead and disrupted signals. The remaining 58 analyses are located within unknown hosts. A U-Pb concordia plot of these analyses yields an upper intercept age of $2380 \pm 120 \mathrm{Ma}$ and a lower intercept of $1043 \pm 190 \mathrm{Ma}$ (MSWD = 618; Figure 6c). Thirty-eight of these analyses were concordant $(<5 \%)$ and used for age calculations. The main peak occurs at $1860 \mathrm{Ma}$, with smaller peaks also occurring at $\sim 1590 \mathrm{Ma}, \sim 2500 \mathrm{Ma}$, and $\sim 2800 \mathrm{Ma}$ (Figure 6d).

\subsection{Zircon Chemistry}

Zircon is hosted within granite, Fe-sericite-altered granite, hematite breccia, hematite, volcanic, quartz, sandstone, K-feldspar, and siltstone clasts, and within the matrix (Table 1). Zircons display typical REE patterns, with enrichment in HREE with positive Ce and mostly negative Eu anomalies (Figure 7a,b). Variability in mean zircon REE content is seen from different clast types (Figure 7a) and from within different drill holes (Figure 7b). Most zircon preserves an HREE fractionation content (HREE Frac $\left.=\mathrm{Gd}_{\mathrm{N}} / \mathrm{Yb}_{\mathrm{N}}\right)$ of $<0.15$ and 
$\mathrm{Eu} / \mathrm{Eu}^{*}$ ratios $\left(\mathrm{Eu} / \mathrm{Eu}^{*}=\mathrm{Eu}_{\mathrm{N}} / \mathrm{sqrt}\left(\mathrm{Sm}_{\mathrm{N}}{ }^{*} \mathrm{Gd}_{\mathrm{N}}\right)\right)$ of $<0.6$ (Figure $\left.7 \mathrm{c}\right)$. This data lies along a background trend of $~ 1: 6$ HREE Frac:Eu/Eu* defined in [15].

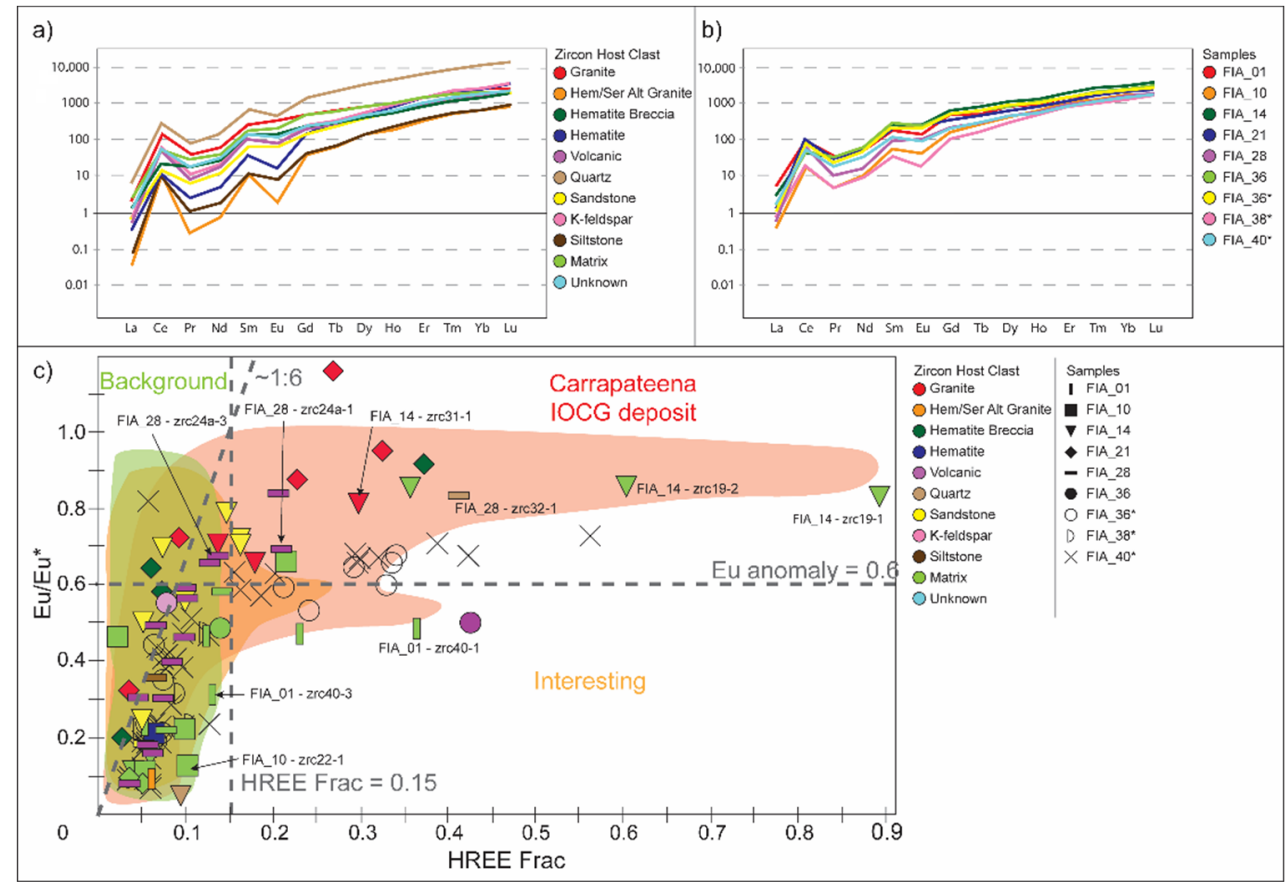

Figure 7. Geochemical plots highlighting the zircon rare-earth element chemistry. (a) Chondrite-normalised REE diagram for zircon in the basal diamictite of the cover sequence, coloured according to hosting clast type. Data normalised to [52]; (b) chondrite-normalised REE diagram for zircon in cover sequence basal diamictite, coloured according to drill hole sample. Data normalised to [52]. Sample and drill hole locations are shown in Figure 1b; (c) heavy rare-earth element (HREE) fractionation vs. Eu/Eu* ratio. HREE Frac $=\mathrm{Yb}_{\mathrm{N}} / \mathrm{Gd}_{\mathrm{N}}$. Data coloured by the type of clast the zircon is hosted by within the basal diamictite. Data shape shows the drill hole from which the sample was taken. Red shading: chemistry of zircon from Donington Suite basement from the Carrapateena area. Orange shading: chemistry of zircon from regional altered samples of the Donington Suite. Green shading: chemistry of zircon from unaltered samples of the Donington Suite. Basement zircon chemistry data taken from [15]. Annotated zircon grains correspond to the internal textures of individual grains shown in Figure 4. * Represents samples analysed from zircon mounts where host clast is unknown.

All samples (except sample FIA_38) preserve zircon with HREE fractionation values of $>0.15$ (Figure $7 \mathrm{c}$ ), which overlap with the chemistry of zircon grains from the underlying Carrapateena deposit [15]. All but seven of these analyses have $\mathrm{Eu} / \mathrm{Eu}^{*}>0.6$ (Figure 7c). The seven analyses with Eu/Eu* ratios are from FIA_36, FIA_01, and FIA_40 samples that are preserved within volcanic clasts and the matrix (Figure 7c). Zircon with high Eu/Eu* ratios (>0.6) occur within samples FIA_10, FIA_14, FIA_21, FIA_28, FIA_36, and FIA_40, and are preserved within the hematite, granite, quartz, sandstone, and volcanic clasts, and within the matrix (Figure 7c).

\section{Discussion}

\subsection{Origin of Zircon within the Basal Diamictite}

The origin of the clasts that sit within the diamictite at the basement-cover unconformity over the Carrapateena area is used to determine the provenance of the zircon hosted within. The clasts comprise granite (including potassic-, Fe-, or sericite-altered granite), granite breccias, volcanics, hematite breccia, hematite, quartz, and siltstone clasts that lie within a matrix of brown, fine- to coarse-grained sandstone (Table 1; Figure 2).

The Carrapateena Breccia Complex hosted within the ca. 1850 Ma Donington Suite immediately underlies the basal diamictite and comprises several lithologies. These include granite- and hematite-dominated breccias that are iron oxide-, quartz-, sericite-, 
K-feldspar-, and chlorite-rich as the result of hydrothermal alteration and mineralisation $[15,29,53]$. The breccia clasts are angular to subrounded and can comprise orthogneiss, granite, siltstone, sandstone, granite, and hematite breccias, volcanics, and a volcanogenic diamictite $[27,29,53]$. Additionally, the Donington Suite that hosts and surrounds the Carrapateena deposit comprises altered granite $[12,27,33,51]$.

$\mathrm{U}-\mathrm{Pb}$ data show that zircons vary in age, with all samples yielding a population at $\sim 1850 \mathrm{Ma}$ for zircon hosted within altered granite, granite, hematite, sandstone, hematite breccia, and K-feldspar clasts (Figures 5 and 6). These clasts have a similar lithological composition to the immediately underlying basement rock packages $[27,29,53]$. The angular to subangular nature of a significant portion of clasts within the diamictite (Table 1) indicates minimal transport distances. Zircons with an age of $\sim 1850 \mathrm{Ma}$ are also present in the matrix of the basal diamictite. The zircon grains overlap in age with the immediately underlying ca. 1850 Ma Donington Suite. This, along with the composition and morphology of the diamictite clasts, is used here to suggest that the zircons are derived from the underlying basement that hosts the Carrapateena deposit. This supports similar interpretations of [34], who also interpret the clasts within the basal diamictite overlying the Carrapateena deposit to have been derived from the immediately underlying mineralised basement rocks.

A smaller population of older zircons are also present in FIA_28, FIA_38, and FIA_40 (Figures 5 and 6 ), yielding $\mathrm{U}-\mathrm{Pb}$ ages of $\sim 2500 \mathrm{Ma}$ and $\sim 2700 \mathrm{Ma}$. These zircons are likely related to the ca. 2480-2420 Ma Sleafordian Orogeny [54]. A dominant $1590 \mathrm{Ma}$ zircon population is present in volcanic clasts from FIA_28 and unknown hosts in FIA_40 (Figure 6). This age coincides with the ca. 1595-1587 Ma Gawler Range Volcanics [55], which were associated with mineralisation across the Olympic Province [13,14]. Volcanics are present in the underlying Carrapateena Deposit [53]; however, the age of these volcanics is unknown. Therefore, these volcanic clasts could be derived from the underlying basement or a distal source.

The presence of subrounded and rounded clasts within the basal diamictite suggests a portion of the clasts were transported from more distal sources. Similar brecciated and altered lithologies to those described in the Carrapateena area and within the basal diamictite are reported within IOCG prospects of Freemantle Doctor and Khamsin that are also host by the Donington Suite and are within $\sim 4$ and $\sim 10 \mathrm{~km}$ of the Carrapateena deposit, respectively [53]. It is therefore possible that the basal diamictite clasts were partially derived from other proximal areas of mineralisation that are also hosted within the Donington Suite and associated with the 1590 Ma mineralising event.

In sample FIA_10, three grains located within the matrix of the basal diamictite yield an average ${ }^{207} \mathrm{~Pb} /{ }^{206} \mathrm{~Pb}$ age of $672 \pm 49 \mathrm{Ma}$, which is consistent with the Umberatana Group which overlies this region [30].

\subsection{Zircon Chemistry in the Clasts}

The preservation of zircon with a composition similar to the demonstrably unique chemistry of zircon from within the Carrapateena orebody suggests that these zircon grains are likely hosted within the clasts interpreted to be derived from the mineralised basement rocks, and not surrounding regions (Figure 7). Reference [15] shows that zircons sourced from Donington Suite samples within the Carrapateena deposit preserve a unique geochemical signature, where zircons from highly brecciated, altered rocks within the orebody can have high $\mathrm{Eu} / \mathrm{Eu}^{*}$ ratios (>0.6) and heavy rare-earth element (HREE) fractionation content (HREE Frac > 0.15). The zircon geochemical signature is demonstrably linked to hydrothermal activity related to the 1600-1570 Ma IOCG mineralising event in the eastern Gawler Craton. This geochemical signature can distinguish zircon within mineralised basement rocks from zircon derived from regional unaltered and altered samples [15]. The regional unaltered and altered samples define a background zircon chemistry described by an HREE Frac:Eu/Eu* ratio of 1:6. A large portion of zircon within the mineralised Carrapateena basement samples also preserves this background trend [15]. The data that plots along the background trend should not be instantly disregarded as having no potential 
for being proximal to IOCG mineralisation, as these grains were interpreted to be resistant to hydrothermal modification, compared to zircons that are more altered and preserve a higher HREE Frac and Eu/Eu* content [15].

The chemistry of several zircons $(n=29)$ derived from clasts within the cover sequence basal diamictite overlaps with the background chemistry of the regional unaltered and altered Donington Suite (Figure $7 \mathrm{c})$. However, several zircon grains $(\mathrm{n}=15)$ from granite, hematite breccia, sandstone, quartz, and volcanic clasts preserve HREE fractionation content of $>0.15$ and an $\mathrm{Eu} / \mathrm{Eu}^{*}$ ratio of $>0.6$, which overlaps with the field of geochemistry characteristic of Carrapateena IOCG deposit zircon (Figure 7c). It is also noted that the zircon grains derived from diamictite clasts have internal fractures and weak to strong oscillatory zoned textures (Figure 4), comparable to zircon from within the Carrapateena deposit [15].

The preservation of zircon that has a comparable composition to the demonstrably unique zircon from within the Carrapateena orebody suggests these zircons are derived directly from the deposit and not from surrounding 1850 Ma Donington Suite granitoids. The preservation of this chemistry suggests the zircon was resistive to geochemical modification during weathering, erosion, transport, and lithification at its new site (see also [56]).

\subsection{Zircon Chemistry in the Matrix}

Zircon grains from the matrix of the cover sequence basal diamictite also preserve chemical characteristics that overlap with both background and interesting geochemical signatures (Figure 7c). Many of the matrix zircons fall within the background chemistry field $(\mathrm{n}=13)$; however, six grains preserve elevated HREE Frac contents $(>0.15)$ (Figure $7 \mathrm{c}$ ). Of these six grains, four grains preserve elevated $\mathrm{Eu} / \mathrm{Eu}^{*}$ ratios $(>0.6)$ and fall within the field defined by zircon characteristics of the Carrapateena deposit (Figure 7c). The other two grains preserve lower $\mathrm{Eu} / \mathrm{Eu}^{*}$ ratios $(<0.6)$ that lie within the interesting field [15].

The matrix-hosted zircon grains are commonly fragmented and can display a higher degree of internal fracturing compared to zircon hosted within clasts (Figure 7). This is likely a result of mechanical weathering of unprotected zircons that were not hosted within clasts. The geochemical signature of elevated HREE fractionation content and $\mathrm{Eu} / \mathrm{Eu}^{*}$ ratios is preserved within the fragmented and fractured matrix-hosted zircon grains (Figure 7), demonstrating that zircon chemistry indicative of IOCG mineralisation can be preserved despite the mechanical breakdown of the zircon.

\subsection{Exploration Criteria Using Zircon in Cover Sequence Materials}

The recognition of zircon within clasts and matrix of the cover sequence basal diamictite that preserves comparable geochemical signature to zircon related to the 1600-1570 Ma IOCG mineralisation event in the Gawler Craton shows that the IOCG exploration criteria developed for zircon within the basement can also be applied to zircon within cover sequences. Therefore, it is likely that the zircon IOCG exploration criteria proposed by [15] is also applicable to zircon preserved in the cover sequences, in particular, zircon grains that yield $\mathrm{Eu} / \mathrm{Eu}^{*}$ ratios of $>0.6$ and HREE fractionation content of $>0.15$, which is considered indicative of being derived from proximal to IOCG mineralisation.

Recent studies investigating zircon chemistry in the Gawler Craton have shown that zircon associated with hydrothermal activity resulting in IOCG mineralisation generally displays increasing REE content with increasing alteration (e.g., potassic, Fe, sericite) [15,57]. REE enrichment is much higher in zircon within zones of mineralisation where alteration of the host rock is most intense [15,57]. Preservation of zircon geochemical signatures that can be related to IOCG mineralisation within clasts and the matrix of the basal diamictite, and that were sourced from the underlying basement, demonstrates the potential for this signature to be dispersed within cover sequence materials. This process will effectively increase the geochemical footprint of the mineralising system. 
The extent of physical dispersion of zircon derived from the Carrapateena area mineralisation within the overlying basal diamictite is difficult to quantify in this study due to the limited number of samples from drill holes immediately surrounding the Carrapateena deposit (Figure 1b). Furthermore, the environment of deposition of the basal diamictite is unequivocal. The assorted shape of clasts preserved within the basal diamictite is indicative of variable degrees of transport. Additionally, the older ( 2500 and $\sim 2700 \mathrm{Ma}$ ) and younger (1590 and $\sim 670 \mathrm{Ma}$ ) zircons suggest the material comprising the diamictite was not solely sourced from the underlying Carrapateena deposit (Figures 5 and 6 ). The fragmented, angular nature of the matrix-hosted zircon grains that yield $1850 \mathrm{Ma}$ ages and preserve elevated HREE fractionation content and $\mathrm{Eu} / \mathrm{Eu}^{*}$ ratios related to Carrapateena mineralisation immediately underlying the basal sequence suggest minimal transport of the matrix-hosted zircon grains. The preservation of these matrix zircons that are highly fractured and angular hematite clasts within the basal diamictite suggests minimal transport, which can occur within glacial environments [6,58]. In this environment, fragments of mineralised basement rock could have been incorporated into the frozen base of the glacier, undergone milling and grinding, and may then have been redeposited [42]. However, the rounded nature of a large portion of clasts is indicative of transportation, which may occur in a fluvioglacial stage during glaciation or within a fluvial environment [59].

Previous studies have shown that mechanical dispersion of geochemical signatures preserved within resistate mineral phases within a glacial environment can result in lateral dispersion up to several hundred meters and even to kilometre scales $[6,7,57,58]$. The pattern of the dispersed geochemical footprint is predictable and is smeared out in the direction of glacial movement $[6,7,60]$. Due to limited understanding of the sedimentology of the basal diamictite overlying the Carrapateena area, the direction of potential glacial movement, and therefore direction of dispersal of a geochemical signature, is currently unknown. Furthermore, fluvial environments have the potential for even greater transport distance, and therefore the creation of even larger dispersion signatures, making zircon analysis an effective method of identifying unrecognised IOCG mineralisation where sediments sampled are sourced from the erosion of mineralised zones.

\subsection{Zircon Criteria Applied to Whole-Rock Geochemistry}

Reference [15] showed that zircon HREE content increases and negative $\mathrm{Eu} / \mathrm{Eu}^{*}$ ratios become more pronounced with increasing IOCG alteration of the host rock. However, mineral exploration companies do not routinely use mineral chemistry (e.g., zircon) in an exploration campaign; rather, whole-rock geochemistry data is routinely collected. Assessment of the HREE fractionation content and $\mathrm{Eu} / \mathrm{Eu}^{*}$ ratios of whole-rock geochemistry data for the cover sequence samples used in this study shows that samples display geochemical characteristics that can be compared to zircon criteria (Figures 7 and 8). The HREE fractionation content of all cover sequence samples is elevated $(>0.15)$ and roughly increases with increasing $\mathrm{Cu}$ content (Figure 8). Elevated $\mathrm{Eu} / \mathrm{Eu}^{*}$ ratios $(>0.6)$ are present in samples from the four drill holes that intersect the deposit, which demonstrates the potential of applying the HREE Frac versus $\mathrm{Eu} / \mathrm{Eu}^{*}$ ratio diagram to whole-rock geochemical data to identify cover sequence samples that may contain elements derived from IOCG mineralisation.

The whole-rock geochemistry Eu/Eu* ratios from samples taken from drill holes that lie up to $\sim 2 \mathrm{~km}$ outside the Carrapateena deposit are low $(<0.6$; samples FIA_01, FIA_36, and FIA_38). These low Eu/Eu* ratios in the whole-rock geochemistry are compared to the $\mathrm{Eu} / \mathrm{Eu}^{*}$ ratios preserved within zircon from the same samples (Figures 7c and 8). Reference [15] showed that zircons with low $\mathrm{Eu} / \mathrm{Eu}^{*}$ ratios $(<0.6)$ and high HREE fractionation content $(>0.15)$ are related to altered granite samples that were proximal to mineralisation but that sat outside of the main orebody. The samples up to $\sim 2 \mathrm{~km}$ outside the Carrapateena deposit (FIA_01, FIA_36, and FIA_38) also preserve a lower degree of potassic alteration relative to samples from within the orebody. 


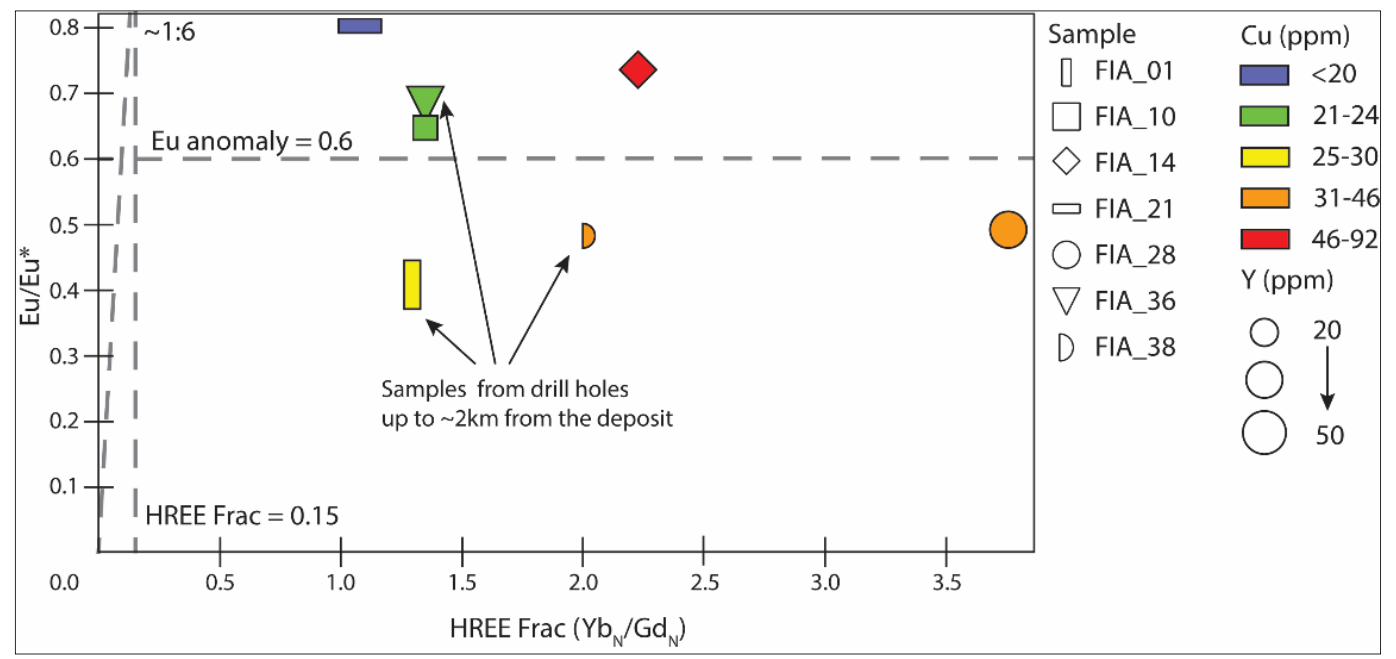

Figure 8. Whole-rock geochemical plot of HREE fractionation content vs. $\mathrm{Eu} / \mathrm{Eu}^{*}$ for samples used in this study. The shape is indicative of the samples; the colour is indicative of the $\mathrm{Cu}$ content and size of $\mathrm{Y}$ content.

Although the HREE fractionation content versus $\mathrm{Eu} / \mathrm{Eu}^{*}$ ratio diagram may be applied to whole-rock geochemical data, the presence of other mineral phases that may influence the REE content of whole-rock geochemical samples needs to be considered. Whole-rock geochemical $\mathrm{Eu} / \mathrm{Eu}^{*}$ ratios can be strongly influenced by feldspar fractionation [61] rather than processes associated with IOCG mineralisation. As feldspars are a major mineral phase, their presence or absence may potentially be visually assessed if there is uncertainty in $\mathrm{Eu} / \mathrm{Eu}^{*}$ ratio results and followed up with feldspar mineral chemistry if needed. Heavy REEs can be enriched in several metamorphic mineral phases including orthopyroxene, amphibole, and garnet (e.g., [62,63]), and also in the common accessory phase xenotime $\left(\mathrm{YPO}_{4}[64]\right)$. The REE pattern in zircon can commonly be influenced by the cocrystallisation of these mineral phases (e.g., orthopyroxene, amphibole, garnet, and xenotime). However, the assessment of enrichment of HREEs into major mineral phases is difficult as the chemistry of these minerals is dominated by major elements (e.g., $\mathrm{Fe}, \mathrm{Mg}$, $\mathrm{Si}$ ) that are likely also present in other common rock-forming minerals. The potential influence of trace minerals, such as xenotime, on HREE content may be considered by comparing the $\mathrm{Y}$ and HREE whole-rock geochemistry content within a sample, where a positive relationship may be indicative of high xenotime content. For the diamictite samples overlying the Carrapateena deposit, no relationship between $Y$ and HREE Frac content was observed (Figure 8), which is not unexpected, as the HREE content of zircon within the samples was directly analysed as being elevated. Additionally, xenotime was rarely observed in the analysed samples and only occasionally forms thin $(<5 \mu \mathrm{m})$ rims around zircon grains. Overall, if the assumption is made that the whole-rock geochemistry $\mathrm{Eu} / \mathrm{Eu}^{*}$ ratios and HREE fractionation content primarily reflect the composition of zircon, then the zircon IOCG geochemical exploration criteria developed in this study can be applied. Whole-rock geochemical data that shows HREE fractionation of $>0.15$ and Eu/Eu* ratios of $>0.6$ may indicate a sample that contains zircon derived from within the zone of Carrapateena-style mineralisation. Whole-rock geochemical data that shows HREE fractionation of $>0.15$ and $\mathrm{Eu} / \mathrm{Eu}^{*}$ ratios of $<0.6$ may be indicative of a sample that has been affected by processes associated with IOCG mineralisation.

\subsection{Future Potential}

The zircon geochemical exploration criteria developed in this study has considerable potential to be applied to existing cover sequence whole-rock geochemical datasets. However, there are considerable limitations and assumptions with the current criteria that would require further investigation. The criteria could also be applied to zircon geochemical data that has already been collected. Zircon mineral chemistry data may 
be available as analysis of zircon separates is commonly performed in geochronological studies; however, not all geochronological studies collect elemental abundance data alongside the isotopic data required for age determination. However, routine simultaneous collection of geochronological and trace element data on zircon are now a realistic goal due to development of new technologies such as the Laser Ablation Split Stream (LASS), which allows for easy collection of trace element data alongside isotope data for geochronology. Collection of such data would not only allow application of the zircon IOCG exploration model developed by [15] and used in this study, but also previously published zircon chemical criteria for porphyry $\mathrm{Cu}-\mathrm{Au}$ mineralisation $[10,16]$. Application of zircon geochemical exploration criteria for multiple commodities using the same dataset would be advantageous in greenfield exploration and broad terrane prospectivity analysis.

The application of zircon exploration criteria to exploration campaigns is limited by the time-consuming sample processing and analytical processes within laboratories, with real-time collection of data at drill sites offering the best approach in the use of the geochemical criteria used in [15] and this study. New, portable technologies such as handheld X-ray fluorescence (XRF) and laser-induced breakdown spectroscopy (LIBS) have been proven to collect reliable in-field whole-rock geochemical data $[65,66]$. Given that this study demonstrated that the zircon geochemical exploration criteria could be applied using whole-rock geochemistry (assuming the $\mathrm{Eu} / \mathrm{Eu}^{*}$ ratio and HREE fractionation content is reflective of zircon chemistry), new handheld technologies may allow for faster application of the criteria. At a drill site, whole-rock geochemical data may be acquired from drill fines collected whilst drilling $[67,68]$. However, it is acknowledged that the low detection limits of portable geochemical analysers may not allow collection of robust geochemical data for all elements required for application of the zircon IOCG exploration criteria. Detection limit issues could potentially be overcome by concentrating geochemical signals through generation of a zircon heavy mineral separate, although a technique for in-field heavy mineral separation is yet to be developed. The effect of collection of zircon chemistry for a whole population, rather than individual spot analyses carried out in this study, would also need to be assessed.

\section{Conclusions}

The cover sequence basal diamictite lying directly at the basement-cover unconformity over the Carrapateena IOCG deposit contains rounded to angular clasts of variable lithology that are primarily $\sim 1850 \mathrm{Ma}$, suggesting they have been derived from the underlying Carrapateena deposit and surrounding Donington Suite host rocks. Geochemical analysis of zircon grains from within the clasts as well as grains within the diamictite matrix preserve geochemical signatures that are comparable to geochemistry of zircon from within the underlying Carrapateena orebody (HREE fractionation > 0.15; Eu/Eu* ratios > 0.6). This geochemical signature can be used to distinguish zircon affected by hydrothermal alteration associated with IOCG mineralisation from background zircon derived from regional unaltered and altered samples of the Donington Suite.

Preservation of the same zircon geochemical signatures in the cover sequence diamictite as well as the underlying mineralised basement rocks demonstrates that the chemistry of zircon is not affected by secondary processes of weathering, erosion, transport, and redeposition. Therefore, there is potential for zircon that preserves a geochemical signature that can be related to IOCG mineralisation to be dispersed within younger cover sequence materials, effectively extending the geochemical footprint of the mineralising system into the overlying cover. The extent to which the geochemical zircon signature has been dispersed within cover sequences directly overlying the Carrapateena orebody is unknown due to uncertainty in the palaeolandscape and depositional environment for cover sequence materials, and the restriction of accessible drill holes to the location of the Carrapateena orebody.

The zircon geochemical exploration criteria may also be applied to whole-rock geochemical data for the cover sequence diamictite overlying the Carrapateena area using 
the same thresholds for HREE fractionation and $\mathrm{Eu} / \mathrm{Eu}^{*}$ ( $>0.15$ and $>0.6$, respectively, for indicating Carrapateena-style IOCG mineralisation). Limitations in using whole-rock geochemical data include understanding whether there are minerals present within the sample that would influence the HREE fractionation and/or Eu/Eu* results (e.g., xenotime, plagioclase).

The outcomes of this study demonstrate that zircon chemistry of cover sequence materials can be used for IOCG exploration. Use of this geochemical exploration tool has the potential to become more standard with development of new technologies that allow simultaneous collection of element abundance and isotopic geochemical datasets and portable whole-rock geochemical technologies.

Supplementary Materials: The following are available online at https:/ / www.mdpi.com/article/10 .3390/min11090916/s1, Supplementary Material S1: Whole rock geochemical data for basal diamictite overlying the Carrapateena deposit; Supplementary Material S2: Zircon BSE and CL images from basal diamictite samples overlying the Carrapateena deposit; Supplementary Material S3: Zircon U-P geochronology and trace element data from basal diamictite samples overlying the Carrapateena deposit.

Author Contributions: Conceptualization, A.B., C.T., D.Z., A.F. and D.G.; formal analysis, A.B. and D.Z.; methodology, A.B., C.T. and D.Z.; validation, A.B., C.T., D.Z., A.F. and D.G.; investigation, A.B., C.T., D.Z., A.F. and D.G.; resources, S.L., B.F.; writing-original draft preparation, A.B., C.T. and D.Z.; writing-review and editing, A.B., C.T., D.Z., A.F., D.G.; visualization, A.B., C.T., D.Z., A.F. and D.G; supervision, A.B., C.T., D.Z., A.F. and D.G; project administration, A.B., C.T. and D.Z.; funding acquisition, A.B., C.T. and D.Z. All authors have read and agreed to the published version of the manuscript.

Funding: This project was kindly supported by the Commonwealth Scholarship for South Australia, the Geological Survey of South Australia, and MinEx CRC, whose activities are funded by the Australian Government's Cooperative Research Centre Programme. This is MinEx CRC document $2021 / 35$.

Data Availability Statement: Data reported in this study are available online at doi:10.17632/dr9n4 fs6zz.1.

Acknowledgments: OZ Minerals is thanked for their assistance in the collection of samples. Anthony Reid is gratefully thanked for assistance with samples. David Kelsey, Aoife McFadden, Benjamin Wade, and Sarah Gilbert from Adelaide Microscopy are also thanked for their help with the collection of SEM and LA-ICP-MS data.

Conflicts of Interest: The authors declare no conflict of interest.

\section{References}

1. Kyser, K.; Barr, J.; Ihlenfeld, C. Applied Geochemistry in Mineral Exploration and Mining. Elements 2015, 11, 241-246. [CrossRef]

2. Schodde, R. Long term trends in global exploration-Are we finding enough metal? In Proceedings of the 11th Fennoscandian Exploration and Mining Conference, Levi, Finland, 31 October 2017.

3. Anand, R.R. Evolution, classification and use of ferruginous regolith materials in gold exploration. Yilgarn Craton, Western Australia. Geochem. Explor. Environ. Anal. 2001, 1, 221-236. [CrossRef]

4. Baudet, E.; Giles, D.; Tiddy, C.; Hill, S. Evaluation of cover sequence geochemical exploration sample media through assessment of element migration processes. Ore Geol. Rev. 2018, 102, 449-473. [CrossRef]

5. Baudet, E.; Tiddy, C.; Giles, D.; Hill, S.; Gordon, G. Diverse provenance of the Lower Cretaceous sediments of the Eromanga Basin, South Australia: Constraints on basin evolution. Aust. J. Earth Sci. 2020, 68, 316-342. [CrossRef]

6. Forbes, C.; Giles, D.; Freeman, H.; Sawyer, M.; Normington, V. Glacial dispersion of hydrothermal monazite in the Prominent Hill deposit: An exploration tool. J. Geochem. Explor. 2015, 156, 10-33. [CrossRef]

7. Plouffe, A.; Ferbey, T.; Hashmi, S.; Ward, B.C. Till geochemistry and mineralogy: Vectoring towards Cu porphyry deposits in British Columbia, Canada. Geochem. Explor. Environ. Anal. 2016, 16, 213232. [CrossRef]

8. Wolff, K.; Tiddy, C.; Giles, D.; Hill, S.M. Pedogenic carbonate sampling for Cu exploration on the Yorke Peninsula, South Australia. J. Geochem. Explor. 2018, 194, 239-256. [CrossRef]

9. Salama, W.; Anand, R.R.; Verrall, M. Mineral exploration and basement mapping in areas of deep transported cover using indicator heavy minerals and paleoredox fronts, Yilgarn Craton, Western Australia. Ore Geol. Rev. 2016, 72, 485-509. [CrossRef] 
10. Lu, Y.-J.; Loucks, R.R.; Fiorentini, M.; Mccuaig, T.C.; Evans, N.J.; Yang, Z.-M.; Hou, Z.-Q.; Kirkland, C.L.; Parra-Avila, L.A.; Kobussen, A. Zircon Compositions as a Pathfnder for Porphyry $\mathrm{Cu} \pm \mathrm{Mo} \pm \mathrm{Au}$ Deposits. Soc. Econ. Geol. Spec. Publ. 2016, 19, 329-347.

11. Plavsa, D.; Tidyy, C.J. Characterisation and dispersion of hydrothermal monazite related to iron oxide-copper-gold mineralisation in South Australia. Future Ind. Accel. (FIA) Rep. 2018, in press.

12. Porter, T.M. The Carrapateena Iron Oxide Copper Gold Deposit, Gawler Craton, South Australia: A Review. In Hydrothermal Iron Oxide Copper-Gold and Related Deposits: A Global Perspective, v. 3-Advances in the Understanding of IOCG Deposits; Porter, T.M., Ed.; PGC Publishing: Adelaide, Australia, 2010; pp. 91-120.

13. Reid, A. The Olympic Cu-Au Province, Gawler Craton: A Review of the Lithospheric Architecture, Geodynamic Setting, Alteration Systems, Cover Successions and Prospectivity. Minerals 2019, 9, 371. [CrossRef]

14. Tiddy, C.; Giles, D. Suprasubduction zone model for metal endowment at 1.60-1.57 Ga in eastern Australia. Ore Geol. Rev. 2020, 122, 103483. [CrossRef]

15. Brotodewo, A.; Tiddy, C.J.; Zivak, D.; Fabris, A.; Giles, D. Zircon U-Pb and trace element chemistry of Donington Suite granites associated with Iron Oxide Copper Gold Deposits in the Gawler Craton, South Australia. Econ. Geol.. in review.

16. Pizarro, H.; Campos, E.; Bouzari, F.; Rousse, S.; Bissig, T.; Gregoire, M.; Riquelme, R. Porphyry Indicator Zircons (PIZs): Application to exploration of Porphyry Copper Deposits. Ore Geol. Rev. 2020, 126, 103891. [CrossRef]

17. Reid, A.J.; Jagodzinski, E.A.; Armit, R.J.; Dutch, R.A.; Kirkland, C.L.; Betts, P.G.; Schaefer, B.F. U-Pb and Hf isotopic evidence for Neoarchean and Paleoproterozoic basement in the buried northern Gawler Craton, South Australia. Precambrian Res. 2014, 250, 127-142. [CrossRef]

18. Hayward, N.; Skirrow, R.G. Geodynamic setting and controls on iron oxide $\mathrm{Cu}-\mathrm{Au}$ (U) Ore in the Gawler Craton, South Australia. In Hydrothermal Iron Oxide Copper-Gold and Related Deposits: A Global Perspective-Advances in the Understanding of IOCG Deposits; Porter, T.M., Ed.; PGC Publishing: Adelaide, Australia, 2010; Volume 3, pp. 119-146.

19. Fairclough, M. Geological and metallogenic setting of the Carrapateena FeO-Cu-Au deposit-A PACE success story. MESA J. 2005, 38, 4-14.

20. Reid, A.; Hand, M.; Jagodzinski, E.; Kelsey, D.; Pearson, N. Paleoproterozoic orogenesis in the southeastern Gawler Craton, South Australia. Aust. J. Earth Sci. 2008, 55, 449-471. [CrossRef]

21. Sawyer, M. Carrapateena and nearby exploration discoveries. In Proceedings of the South Australian Exploration and Mining Conference, Adelaide, Australia, 25 November-3 December 2013.

22. Gow, P.A.; Wall, V.J.; Oliver, N.H.S.; Valenta, R.K. Proterozoic iron oxide (Cu-U-Au-REE) deposits: Further evidence of hydrothermal origins. Geology 1994, 22, 633-636. [CrossRef]

23. Apukhtina, O.B.; Kamenetsky, V.S.; Ehrig, K.; Kamenetsky, M.B.; Maas, R.; Thompson, J.; Mcphie, J.; Ciobanu, C.L.; Cook, N.J. Early, deep magnetite-fluorapatite mineralisation at the Olympic Dam Cu-U-Au-Ag deposit, South Australia. Econ. Geol. 2017, 112, 1531-1542. [CrossRef]

24. Ehrig, K.; Mcphie, J.; Kamenetsky, V. Geology and mineralogical zonation of the olympic dam iron oxide Cu-U-Au-Ag deposit, South Australia. Soc. Econ. Geol. Spec. Publ. 2012, 16, 237-267.

25. Belperio, A.; Flint, R.; Freeman, H. Prominent Hill: A hematite-dominated, iron oxide-copper-gold system. Econ. Geol. 2007, 102, 1499-1510. [CrossRef]

26. Drexel, J.F.; Preiss, W.V. The geology of South Australia. S. Aust. Geol. Surv. Bull. 1995, 2, 357.

27. Vella, L.; Cawood, M. Carrapateena: Discovery of an Olympic Dam-style deposit: Preview. ASEG Ext. Abstr. 2006, 122, 26-30.

28. Mortimer, G.E. Early to Middle Proterozoic Granitoids, Basaltic Dykes and Associated Layered Rocks of S.E. Eyre Peninsula, South Australia. Ph.D. Thesis, University of Adelaide, Adelaide, Australia, 1984; 189p.

29. Kleeman, A. The Petrology and trace Element Geochemistry of the Carrapateena Deposit, Olympic IOCG Province, South Australia. Honours Thesis, University of Tasmania, Hobart, Australia, 2012; 113p. unpublished.

30. Lloyd, J.; Blades, M.; Counts, J.; Collins, A.; Amos, K.; Wade, B. Neoproterozoic geochronology and provenance of the Adelaide Superbasin. Precambrian Res. 2020, 350, 105849. [CrossRef]

31. Preiss, W.V. (compiler); Adelaide Geosyncline-late Proterozoic stratigraphy, sedimentation, palaeontology and tectonics. In Bulletin 53; Geological Survey of South Australia: Adelaide, Australi, 1987.

32. Tonkin, D. Recognition and definition of the copper-hosting Whyalla Sandstone, South Australia. MESA J. 2019, 89, 39-44.

33. Vella, L.; Emerson, D.W. Carrapateena: Physical properties of a new iron-oxide copper-gold deposit. In Proceedings of the 20th International Geophysical Conference and Exhibition, Adelaide, Australia, 12 February 2009; Extended Abstracts. pp. 1-13.

34. Tiddy, C.; Zivak, D.; Hill, J.; Giles, D.; Hodgkison, J.; Neumann, M.; Brotodewo, A. Monazite as an Exploration Tool for Iron Oxide-Copper-Gold Mineralisation in the Gawler Craton, South Australia. Minerals 2021, 11, 809. [CrossRef]

35. Preiss, W.V.; Dyson, I.A.; Reid, P.W.; Cowley, W.M. Revision of lithostratigraphic classification of the Umberatana Group. MESA J. 1998, 9, 36-42.

36. González-Álvarez, I.; Ley-Cooper, A.-Y.; Salama, W. A geological assessment of airborne electromagnetics for mineral exploration through deeply weathered profiles in the southeast Yilgarn Cratonic margin, Western Australia. Ore Geol. Rev. 2016, 73, 522-539. [CrossRef]

37. González-Álvarez, I.; Boni, M.; Anand, R.R. Mineral exploration in regolith-dominated terrains: Global considerations and challenges. Ore Geol. Rev. 2016, 73, 375-379. [CrossRef] 
38. Anand, R.R. Regolith-landform processes and geochemical exploration for base metal deposits in regolith-dominated terrains of the Mt Isa region, northwest Queensland, Australia. Ore Geol. Rev. 2016, 73, 451-474. [CrossRef]

39. Brown, L.; Vearncombe, J. Critical analysis of successful gold exploration methods. Appl. Earth Sci. Trans. Inst. Min. Metall. 2014, 123, 18-24. [CrossRef]

40. Cameron, E.M.; Leybourne, M.I.; Kelley, D.L. Exploring for deposits under deep cover using geochemistry. Soc. Econ. Geol. Newsl. 2005, 63, 5-15.

41. Cornelius, M.; Potto, C.G.; Dunn, C.E.; Butt, C.R.M.; Oates, C.; Coelho, R. Soil and biogeochemical signatures of the Aripuana base metal deposit, Mato Grosso, Brazil. Geochem. Explor. Environ. Anal. 2007, 7, 179-192. [CrossRef]

42. Mcclenaghan, M.; Paulen, R. Application of Till Mineralogy and Geochemistry to Mineral Exploration. Past Glacial Environ. 2018, 689-751. [CrossRef]

43. Anand, R.R.; Phang, C.; Wilford, J.; Wildman, J.E.; Li, S.; Robertson, I.D.M.; Munday, T.J. Regolith-Landscape Characteristics, Evolution and Regional Synthesis of the Mt Isa Region: Progress Report; Cooperative Research Centre for Landscape Evolution and Mineral Exploration: Wembley, Australia, 1996; Volume 125, pp. 35-38.

44. Cameron, E.M.; Leybourne, M.I.; Kelley, D.L. Exploring for deeply covered mineral deposits: Formation of geochemical anomalies in northern Chile by earthquake-induced surface flooding of mineralised groundwaters. Geology 2002, 30, 1007-1010. [CrossRef]

45. Cameron, E.M.; Leybourne, M.I. Relationship between groundwater chemistry and soil geochemical anomalies at the Spence copper porphyry deposit, Chile. Geochem. Explor. Environ. Anal. 2005, 5, 135-145. [CrossRef]

46. Anand, R.R.; Robertson, I.D.M. The role of mineralogy and geochemistry in forming anomalies on interfaces and in areas of deep basin cover: Implications for exploration. Geochem. Explor. Environ. Anal. 2012, 12, 45-66. [CrossRef]

47. Rose, A.W.; Hawkes, H.E.; Webb, J.S. Geochemistry in Mineral Exploration, 2nd ed.; Academic Press: New York, NY, USA, 1979; $655 \mathrm{p}$.

48. Košler, J. Laser ablation sampling strategies for concentration and isotope ratio analyses by ICP-MS. In Laser Ablation ICP-MS in the Earth Sciences: Current Practices and Outstanding Issues (P. Sylvester, ed.). Mineral. Assoc. Can. Short Course Ser. 2008, 40, 79-92.

49. Paton, C.; Hellstrom, J.; Paul, B.; Woodhead, J.; Hergt, J. Iolite: Freeware for the visualisation and processing of mass spectrometric data. J. Anal. At. Spectrom. 2011, 26, 2508. [CrossRef]

50. Longerich, H.P.; Jackson, S.E.; Günther, D. Laser ablation inductively coupled plasma mass spectrometric transient signal data acquisition and analyte concentration calculation. J. Anal. At. Spectrom. 1996, 11, 899-904. [CrossRef]

51. Sawyer, M.; Whittaker, B.; de Little, J. Carrapateena iron oxide Cu-Au-Ag-U deposit. In Australian Ore Deposits; Phillips, G.N., Ed.; The Australasian Institute of Mining and Metallurgy Monograph 32, Australian Institute of Mining and Metallurgy: Carlton, Australia, 2017; pp. 615-620.

52. Taylor, S.R.; Mclennan, S.M. The Continental Crust: Its Composition and Evolution; Blackwell Scientific Publications: Oxford, UK, 1985.

53. Neumann, M. IOCG Workshop-Gawler Craton. Stuart Shelf Hematite Rich End Members. In Proceedings of the Geological Survey of South Australia Iron Oxide-Copper-Gold Mineral Systems Workshop; Adelaide, Australia, 2-3 December 2019. Available online: https:/ / www.energymining.sa.gov.au/_data/assets/pdf_file/0003/355008/09_Mitchell_Neumann.pdf (accessed on 20 November 2020).

54. Hand, M.; Reid, A.; Jagodzinski, E. Tectonic framework and evolution of the Gawler Craton, Southern Australia. Econ. Geol. 2007, 102, 1377-1395. [CrossRef]

55. Cherry, A.; Ehrig, K.; Kamenetsky, V.; Mcphie, J.; Crowley, J.; Kamenetsky, M. Precise geochronological constraints on the origin, setting and incorporation of ca. 1.59 Ga surficial facies into the Olympic Dam Breccia Complex, South Australia. Precambrian Res. 2018, 315, 162-178. [CrossRef]

56. Corfu, F.; Hanchar, J.M.; Hoskin, P.W.O.; Kinny, P. Atlas of zircon textures. Rev. Mineral. Geochem. 2003, 53, 469-500. [CrossRef]

57. Courtney-Davies, L.; Ciobanu, C.L.; Verdugo-Ihl, M.R.; Slattery, A.; Cook, N.J.; Dmitrijeva, M.; Keyser, W.; Wade, B.P.; Domnick, U.I.; Ehrig, K.; et al. Zircon at the Nanoscale Records Metasomatic Processes Leading to Large Magmatic-Hydrothermal Ore Systems. Minerals 2019, 9, 364. [CrossRef]

58. Ashley, G.M.; Shaw, J.; Smith, N.D. Glacial sedimentary environments. In SEPM Short Course No. 16; Society of Palaeontologists and Mineralogists: Tulsa, OK, USA, 1985.

59. Huddart, D.; Bennett, M.; Hambrey, M.; Glasser, N.; Crawford, K. Origin of well-rounded gravels in glacial deposits from Brøggerhalvøya, northwest Spitsbergen: Potential problems caused by sediment reworking in the glacial environment. Polar Res. 1998, 17, 61-70. [CrossRef]

60. Mcclenaghan, M.B.; Thorleifson, L.H.; Dilabio, R.N.W. Till geochemical and indicator mineral methods in mineral exploration. Ore Geol. Rev. 2000, 16, 145-166. [CrossRef]

61. Fowler, A.; Doig, R. The significance of europium anomalies in the REE spectra of granites and pegmatites, Mont Laurier, Quebec. Geochim. Cosmochim. Acta. 1983, 47, 1131-1137. [CrossRef]

62. Fornelli, A.; Langone, A.; Micheletti, F. The role of trace element partitioning between garnet, zircon and orthopyroxene on the interpretation of zircon $\mathrm{U}-\mathrm{Pb}$ ages: An example from high-grade basement in Calabria (Southern Italy). Int J Earth Sci (Geol Rundsch). 2014, 103, 487-507. [CrossRef] 
63. Fornelli, A.; Langone, A.; Micheletti, F.; Piccarreta, G. REE partition among zircon, orthopyroxene, amphibole and garnet in a high-grade metabasic system. Geol. Mag. 2018, 155, 1705-1726. [CrossRef]

64. Richter, L.; Diamond, L.; Atanasova, P.; Banks, D.; Gutzmer, J. Hydrothermal formation of heavy rare earth element (HREE)xenotime deposits at $100{ }^{\circ} \mathrm{C}$ in a sedimentary basin. Geology. 2018, 46, 263-266. [CrossRef]

65. Fisher, L.; Gazley, M.; Baensch, A.; Barnes, S.; Cleverley, J.; Duclaux, G. Resolution of geochemical and lithostratigraphic complexity: A workflow for application of portable X-ray fluorescence to mineral exploration. Geochem. Explor. Environ. Anal. 2021, 14, 149-159. [CrossRef]

66. Senesi, G.; Harmon, R.; Hark, R. Field-portable and handheld laser-induced breakdown spectroscopy: Historical review, current status and future prospects. Spectrochim. Acta Part B At. Spectrosc. 2021, 175, 106013. [CrossRef]

67. Hillis, R.R.; Giles, D.; Van Der Wielen, S.E.; Baensch, A.; Cleverley, J.S.; Fabris, A.; Uvarova, Y. Coiled tubing drilling and realtime sensing-enabling prospecting drilling in the 21st Century? Soc. Econ. Geol. Spec. Publ. 2016, 18, 243-259.

68. Uvarova, Y.; Gazley, M.; Cleverley, J.; Baensch, A.; Lawie, D.; Legras, M. Representative, high-spatial resolution geochemistry from diamond drill fines (powders): An example from Brukunga, Adelaide, South Australia. J. Geochem. Explor. 2016, 170, 1-9. [CrossRef] 